\title{
BESCHRIJVEND GEDEELTE.
}

\section{A. Definities.}

Gelijk men voor de soorten der veeren, wat den vorm aangaat, namen heeft moeten instellen als daar zijn donsveer, slagpen, contourveer enz., welke namen op sommige veeren niet steeds even gelukkig van toepassing zijn als op andere, zoo ben ik ook genoodzaakt geweest voor de beschrijving van het veerenpatroon enkele begrippen door definities vast te leggen. Door het vastleggen dier begrippen, welke soms zoo vanzelf sprekend lijken, maar zooals uit de literatuur blijkt, ondanks alle vanzelfsprekendheid toch rnet elkaar verward worden, vervalt men niet in voortdurende en vervelende herhalingen en vermijdt men allerlei vergissingen en onduidelijkheden.

Kende men van de teekeningen en kleuren der veeren de bepaalde regels van phylogenetische opvolging, dus hun phylogenetische waarde, dan zou men dit bij de beschrijving zeer zeker in aanmerking kunnen en moeten nemen. Men zon dan b.v. met het begrip ondergrond de phylogenetisch oudere, met het begrip teekening de phylogenetisch jongere kleur of figuur van een veer moeten bestempelen. Daar men dit nu echter van te voren niet weten kan en men desondanks toch voor vergelijkingen en besprekingen genoodzaakt is bepaalde begrippen in te voeren, is men derhalve wel gedwongen deze begrippen vast te stellen door definitie. Deze begrippen, namen voor figuren enz., hebben derhalve een uitsluitend descriptieve waarde, en het is dus zeer goed mogelijk, dat ik een kleur als ondergrond beschrijf, welke later misschien blijken zal de phylogenetisch jongste kleur te zijn. Ik herhaal dus: al mijne benamingen hebben slechts een descriptieve waarde.

Voor zoover nu de veerfiguren niet geheel met mijn definities in overeenstemming zijn, heb ik bij het gebruik van mijne namen er verzwakkende of versterkende opmerkingen aan toegevoegd. Zoo vindt men vaak verlengde, afgeplatte, hoekige enz. "vlekken" of wel onderbroken, zigzagswijze verloopende enz. „banden". Ik geloof dat dergelijke benoemingen geheel vanzelf zullen spreken.

Het is mij bij mijn onderzoek gebleken hoe goed het is zich steeds van gelijkluidende definities te bedienen. Door het gebruik van steeds gelijkluidende termen valt het oog deste eerder op verschillen, welke men anders over het hoofd zou zien, en is men als het ware gedwongen tot het doen van een zuivere waarneming. Als voorbeeld hoe gemakkelijk men iets over het hoofd kan zien, wil ik noemen de beschrijving van Bonv, die experimenteele onderzoekingen deed over veeren van fazanten; welke veeren tegelijkertijd een manlijk en vrouwlijk karakter zouden dragen. Hier was n.l. de linker vlaghelft voorzien van een ander patroon dan de rechter vlaghelft bij eenzelfde veer. Bond meent hieruit te moeten besluiten, dat deze staartveeren aan de eene zijde een manlijk patroon en aan de andere zijde een vrouwlijk patroon dragen en hij meent met een onduidelijke fotografie zonder eenige nadere beschrijving te kunnen volstaan. Wanneer hij zich de moeite gegeven had de veeren te be- 
schrijven, zou het hem allicht zijn opgevallen, dat het z.g. vrouwlijk patroon volstrekt geen vrouwlijk patroon is, maar een typisch manlijk. Ik haal dit slechts als voorbeeld aan om te wijzen op de noodzakelijkheid van het beschrijven. Hoe gelijkluidender de beschrijvingen zijn, voor zoover het gebruik der beschrijvingstermen betreft, des te beter zullen zij een gemakkelijke vergelijking toelaten.

Ik wil derhalve een voor een de definities opstellen en ik zal die eventueel door een enkele opmerking verduidelijken. Ik heb bij het opstellen zooveel mogelijk namen gekozen, welke in overeenstemming zijn met de gangbare inzichten. De definities luiden nu aldus:

a. Ondergrond = kleur der hoofdmassa van de veervlag, tenzij deze hoofdmassa begrensd is door lijnen, welke een der zoo aanstonds te noemen typische figuren doen ontstaan. In twijfelachtige gevallen wordt steeds het gewicht gelegd op de grootte, dus de uitgestrektheid van de kleur.

b. Teekening $=$ kleur, welke aanleiding geeft tot het ontstaan van een der zoo aanstonds te noemen of mogelijk nog andere figuren, waarbij dus de hoeveelheid kleuroppervlak van de figuur kleiner is dan die van den ondergrond. In twijfelachtige gevallen wordt steeds het gewicht gelegd op den typischen vorm van de kleur. Men bedenke hierbij, dat een figuur of teekening zich slechts uiten kan door kleur-verschillen. De soort van kleur heeft met de teekening verder niets uit te staan.

De vormen der teekeningen kan men nu indeelen volgens veel voorkomende tiguren. Aldus:

$\mathbf{1}^{0}$. Stip $=$ Min of meer afgeronde, eenkleurige, anderskleurige plek met gemiddelde middellijn kleiner dan 1 millimeter.

Hierbij moet nog opgemerkt worden, dat anderskleurig beteekent: tegen de onmiddellijke omgeving zich door eigen kleur onderscheidend. Ik zal kleurverschillen alle waarneembare verschillen noemen zonder onderscheid. Deze kunnen dus tot stand komen door pigmentatie, door diffractie, reflectie of wel prismabreking (zie GADOw) ${ }^{1}$ ). De grens van 1 millimeter voor de kortste as van een stip kan bij de beschrijving van een geheele veer wel degelijk door enkele stippen overschreden worden, mits dat hun aantal een kleine minderheid blijft.

$2^{0}$. $V l e k=$ Min of meer afgeronde, eenkleurige, anderskleurige plek met gemiddelde kortste as, grooter dan 1 millimeter.

Opmerkingen als bij "stip", doch hier kan natuurlijk de kortste as in een enkel geval ook wel eens onder den maat zijn.

$3^{0}$. Streep $=$ Lijnvormig uitgerekte, eenkleurige, anderskleurige strook met gemiddelde kortste as kleiner dan 1 millimeter (dus gelijk aan verlengde stip).

Opmerkingen als bij "stip".

$4^{0}$. Band $=$ Lijnvormig uitgerekte, eenkleurige, anderkleurige strook met gemiddelde kortste as grooter dan 1 millimeter (dus gelijk aan verlengde vlek).

Opmerkingen als bij „vlek".

$5^{0}$. Samengestelde of complexe band $=$ Band bestaand uit eenkleurige, anderskleurige middenstrook met aan weerszijden onderling gelijkkleurige, eenkleurige, anderskleurige stroken. Hierbij zijn deze gepaarde stroken natuurlijk zoowel anderskleurig ten opzichte van den ondergrond als ten opzichte van de ongepaarde strook. Waarschijnlijk gaat de anderskleurigheid ten opzichte van den ondergrond vaak verloren en verkrijgt men dus feitelijk een verdubbeld aantal banden, wanneer dit bij de ongepaarde

1) Slechts één soort `van kleur heeft met teekening of ondergrond niets uit te staan, namelijk die kleur, welke van buiten af op de veeren aangebracht wordt. Ik vond deze, overigens zeer zeldzame kleuruiting slechts bij één vogel eń wel bij Dichoceros bicornis $\left(L_{\text {. }}\right.$, een neushoornvogel. Dit dier verft geregeld den bovensnavel en tegelijkertijd de kopen nekveeren alsmede de licht-grijze vleugeldekveeren okergeel, doordat het het okergele vet van den stuitklier op deze plaatsen uitwrijft. Een dergelijke wijze van a.h. w. kunstmatige lichaamskleuring is ook éénmaal bij zoogdieren gevonden door WEBER bij Macropus rufus $\sigma^{7}$ (zie „Biologie"), den rooden-kangeroe. Het is mij niet bekend of bij dezen neushoornvogel ook een dergelijk verschil voor de geslachten bestaat. Ik hoop hierop in een latere studie terug te komen, en kan nu volstaan met te wijzen op dit hoogst merkwaardig verschijnsel, dat valt op het gebied der veerkleur. 
strook plaats vindt. Slechts bij duidelijk kleurverschil spreek ik van samengestelde of complexe banden.

Opmerkingen als bij „band".

Bij de strepen en banden kan men nog weer vier veelvuldig optredende vormen onderscheiden:

I. Dwarse = van veerrand naar veerschacht, onder een hoek van $90^{\circ}$ op de veerschacht verloopende strook.

II. Scheefgestelde = als eerste, maar onder een hoek grooter of kleiner dan $90^{\circ}$ op de veerschacht verloopende strook.

III. Overlangsche $=$ van veervoet naar veertop evenwijdig (dus met een hoek van $180^{\circ}$ ) aan de veerschacht verloopende strook.

IV. Randstandige $=$ met den veerrand evenwijdig verloopende dus meestal niet rechte strook. Dergelijke stroken kunnen, mede in verband met den veervorm, de schacht éénmaal, in dit geval aan den veertop, of twéémaal, in dit geval aan den veertop en aan. den veervoet, snijden. Terloops zij hier nog opgemerkt, dat in de literatuur randstandige stroken vaak als echte overlangsche stroken beschreven zijn. Dit is dus onjuist.

$6^{\circ}$. Ringvlek $=$ Vlek bestaande uit een eenkleurig, anderskleurig centrum, omgeven door een of meer eenkleurige, anderskleurige ringen.

Opmerkingen als bij "vlek".

70. Oogvlek of Ocellus = Bijzonder geval van ringvlek, echter door zeer gespecialiseerde plaatsing, aantal, relatieve grootte, bouw enz. bijzonder opvallende vlek.

Hiermede is dus gezegd, dat het begrip oogvlek, waarvoor meestal de naam ocellus gebruikt wordt, en waaruit dus blijkt, dat het een zeer algemeen bekende figuur is, niets anders is, dan een ringvlek, welke een zeer sterke specialisatie heeft ondergaan. Men moet dus steeds in elk nieuw geval die specialisatie nader toelichten en men kan dus volstrekt niet b. v. door de kennis van den ocellus der Pauwhanen zonder nadere kennis van het bepaalde geval, zich een goed beeld maken van den oogvlek van een anderen vogel. Slechts dit gemeenschappelijks hebben alle ocelli, dat zij steeds meer of minder samengestelde ringvlekken zijn.

Opmerkingen als bij ,vlek".

8. Dubbele Ringvlek = Geheel als ringvlek, doch men treft er twee centra aan. Hiervan kan men weer twee vormen onderscheiden:

$a$. Niet over de veerschacht heengrijpende, dubbele ringvlekken.

$b$. Wel over de veerschacht heengrijpende, dubbele ringvlekken.

Opmerkingen als bij "vlek".

9. Dubbele Oogvlek = Geheel als oogvlek, doch men treft er twee centra aan. Van deze soort vlekken is mij slechts een vorm bekend n. l.: "wel over de veerschacht heengrijpende, dubbele oogvlekken". Maar ook deze vorm is mij slechts bekend van gevallen, die overgangsvormen voorstellen van normale oogvlekdragende veeren, welke in 't geheel geen oogvlek meer dragen. Het schijnt dus, dat bij de oogvlekken de versmelting zoo innig is, dat men slechts met moeite en bij uitzondering de beide centra daarvan herkennen kan. Immers de over de schacht heengrijpende dubbele ringen oogvlekken hebben hoogstwaarschijnlijk haar ontstaan te danken aan de versmelting van twee losse centra. Daarmede behoeft nog niet gezegd te zijn, dat er tijdens de innige versmelting dier beide centra reeds sprake was van eigenlijke vlekken. Integendeel is het veel waarschijnlijker, dat men toen nog met dwarsbanden op de beide vlaghelften der veeren te doen had. Daarentegen is het van niet over de veerschacht heengrijpende, dubbele vlekken veel meer waarschijnlijk, dat deze vlekken niet door versmelting maar door een begin van splitsing zijn ontstaan. In het meer bijzonder overzicht zal ik daar nader op terugkomen.

Opmerkingen als bij "vlek". 
De zoo juist genoemde 9 soorten van teekeningen of figuren komen alle als zoodanig bij de hoenderachtige vogels geregeld voor. Men treft vaak meerdere tegelijk aan op een individu, of wel men vindt ze verdeeld over zeer naverwante soorten. Aan deze algemeen voorkomende vormen kan ik nog een enkele niet algemeen verbreide vorm toevoegen. Deze figuren zijn zeer typisch en komen bij een enkele vogelsoort zeer veelvuldig voor. Deze vormen zijn :

$10^{\circ}$. Ruitvormige Vlek $=$ Een ongepaarde, eenkleurige, anderskleurige, naar boven en onder uitgerekte, ruitvormige plek, welke dus door vier nagenoeg rechte lijnen begrensd wordt.

110. Celvormige teekening $=$ Een door zes rechte lïnen begrensde figuur, in wier centrum een stip gelegen is. De figuur doet denken aan een doorgesneden bijencel.

Hoewel het hier niet heelemaal ter plaatse is, meen ik er nu reeds aan te moeten toevoegen, dat al deze teekeningen en figuren slechts schijnbaar een zekere individualiteit vertoonen. Deze figuren zijn naar mijne meening geen werkelijke eenheden, maar slechts componenten van geheel andere, niet zichtbare factoren. Dit geldt zoowel voor die figuren, welke door reflexkleuren ontstaan, als voor de door pigment of anderzins gevormde beelden. Een nadere bespreking hierover vindt men in het meer algemeen overzicht.

Aan deze definities, welke den vorm, kleur en teekening der veeren beschrijven, moet ik nog een paar andere definities toevoegen. Deze beide definities betreffen niet, gelijk de elf bovenstaanden, de eigenschappen van één veer, zij bepalen de eigenschappen van meerdere veeren tegelijk, dus van veergroepen. Deze beide definities Juiden aldus:

I. Veerveld: Deel van het veerkleed, dat gevormd wordt door een groep (neestal bestaande uit zeer vele exemplaren) naast elkaar gelegen veeren, welke allen hetzij in vorm, in kleur of in teekening een of meer opvallende, hoewel in ongelijke mate ontwikkelde eigenschap gemeen hebben. Door deze opvallende eigenschap(pen) lijkt de geheele veergroep op .het eerste gezicht (dus b.v. aan den levenden vogel) eenvormig te zijn, daar deze eene of meerdere veereigenschap(pen) de veergroep, dus het uiterlijk van den vogel, op een bepaalde lichaamsplek volkomen typeert(en).

Hierbij moet echter opgemerkt worden, dat een veerveld slechts schijnbaar een scherp afgegrensd veld is, daar er in werkelijkheid volstrekt geen scherpe grenzen zijn, en zelfs de uiterste veeren van het veerveld nauwelijks meer de veereigenschap(pen) van dit bepaalde veld dragen.

II. Veereditie: Samenvatting voor alle veeren van eenzelfden vogel (zoowel de nog inplante veeren, als de reeds uitgevallen veeren), welke tijdens of door eenzelfden rui ontstonden. Hier wordt dus het gewicht gelegd op het tijdstip van den rui en niet op het tegelijkertijd aanwezig zijn der veeren, noch op het rangnummer van den rui. Terwijl men alle veeren van een vogel ten allen tijde tezamen met den naam van veerkleed moet bestempelen, zullen toch meestal de veeren van een veerkleed niet zijn ontstaan tijdens of door den zelfden rui, zooals de ervaring leert. De veeren van een vogel vormen dus tegelijkertijd een veerkleed maar behooren tegelijkertijd tot meerdere (twee, soms drie) veeredities. Er bestaat dus een principieel verschil tusschen veerkleed en veereditie. Bij de beoordeeling van het veerpatroon (zoowel voor vorm, voor teekening en voor kleur) zal het verschil tusschen veerkleed en veereditie zeer duidelijk op den voorgrond treden. Bij de veeren van een veereditie treft men meestal geleidelijke overgangen aan tusschen de verschillende veeren, bij de veeren van een veerkleed is dat vaak niet zoo. 


\title{
$B$. Lijst der meer nauwkeurig onderzochte Hoenderachtige Vogels.
}

De vogelnamen, welke deze lijst bevat, zijn de namen dier hoenderachtige vogels, welke aan een meer nauwkeurig onderzoek onderworpen werden en die, hoewel lang niet allen als demonstratie-object in het beschrijvend gedeelte van dit werk zijn opgenomen, toch allen tot den grondslag gerekend mogen worden, waarop het overzicht steunt. Uit deze lijst van vogels hebben dus slechts weinigen een plaats gevonden in het beschrijvend gedeelte, daar het mij voorkwam, dat ik met een enkel gedocumenteerd voorbeeld kon volstaan, aangezien geen der hier opgesomde vogels verschijnselen vertoont, welke in strijd zijn met de conclusies, die ik uit de weinige genoemden trok (zie Opsomming der conclusies). De bedoeling dezer dorre opsomming van namen ligt dus hierin om den lezer den indruk te ontnemen, dat bovengenoemde conclusies slechts op een enkel waargenomen feit bij een enkelen vogel gebaseerd zouden zijn. Bovendien kan ik hier nog aan toevoegen, dat ik van verscheidene der genoemde soorten niet slechts één haan en één hen bestudeerde, maar dat ik van velen meerdere exemplaren in handen kreeg, van enkele soorten zelfs vele tientallen.

Het was mij onmogelijk en ook leek het mij overbodig toe een opsomming te geven van alle andere (zoowel hoenderachtige als niet hoenderachtige) vogels, welke ik gedurende de laatste jaren op hun veereigenschappen nakeek. Ware dit wel het geval geweest, dan zou natuurlijk de hier volgende lijst nog heel veel uitgebreider geworden zijn, en zou men er vele namen van systematisch ver verwijderde geslachten in hebben aangetroffen.

Ik meende derhalve, met het opnoemen van de hiervolgende soorten te kunnen volstaan:

\author{
Acomus erythrophthalmus Raffl. \\ Acomus pyronotus Gray. \\ Acryllium vulturinum Hardw. \\ Arboricola atrigulares Blyth. \\ Argusianus argus L. \\ Argusianus grayi Elliot. \\ Bambusicola sonorivox Gould. \\ Bonasa umbellus L. \\ Caccabis chukar Gray. \\ Caccabis petrosa $\mathrm{Gm}$. \\ Caccabis rufa $\mathrm{L}$ \\ Caloperdix oculea Temm. \\ Calophasis ellioti. Swinh. \\ Catherurus lathami Lath. \\ Centrocercus urophasianus Bonap. \\ Colinus virginianus L. \\ Coturnix coturnix L. \\ Coturnix novae-zealandiae Q. et $\mathrm{G}$. \\ Crossoptilon manchuricum Newt. \\ Cyrtonix montezumae Vig. \\ Eulipoa wallacei Gray. \\ Eupsychortyx cristatus L. \\ Excalfactoria chinensis L. \\ Francolinus africanus Steph. \\ Francolinus capensis Gm. \\ Francolinus erckeli Rüpp. \\ Francolinus francolinus L. \\ Francolinus levaillanti Valenc. \\ Grallus aeneus Temm.
}


Gallus gallus L.

Gallus sonnerati Temm.

Gallus varius Shaw et Nodd.

Gennaeus albicristatus Vig.

G'ennaeus horsfieldi Gray.

Gennaeus lineatus Vig.

Gennaeus melanotus Blyth.

Gennaeus nycthemerus $\mathrm{L}$.

Gennaeus swinhoei Gould.

Guttera cristata Pall.

Ithagenes cruentus Hardw.

Lagopus lagopus L.

Lagopus mutus Mont.

Lagopus rupestris Gm.

Lagopus scoticus Lath.

Lobiophasis bulweri Sharpe.

Lophophorus impeyanus Lath.

Lophortyx californicus Shaw.

Lophura diardi Temm.

Lophura ignita Shaw.

Lophura rufa Raffl.

Lyrurus tetrix $\mathbf{L}$.

Megacephalon maleo Bartl.

Megapodius spec.

Meleagris americana Bartr.

Meleagris ocellata Cuv.

Numida meleagris L.

Numida mitrata Pall.

Numida ptilorhyncha Licht.

Odontophorus capucira Spix.

Odontophorus guianensis Gm.

Oreophasis derbianus Gray.

Oreortyx pictus Dougl.

Pavo cristatus L.

Pavo hybridus (cristatus $\times$ cristatus var. alba).

Pavo muticus L.

Pavo nigripennis Sclat.

Perdicula asiatica Lath.

Perdix daurica Pall.

Perdix perdix L.

Phasianus colchicus. L.

Phasianus mongolicus Brandt.

Phasianus principalis Sel.

Phasianus satcheunensis Przev.

Phasianus semitorquatus Sev.

Phasianus soemmeringii Temm.

Phasianus torquatus Gm.

Phasianus versicolor Vieill.

Polyplectron bicalcaratum L.

Polyplectron chinquis Müll.

Pternistes cranchi Leach.

Pternistes nudicollis Bodd. 
Pucrasia macrolopha Less. Rhizothera longirostris Temm. Rollulus roulroul Scop. Synoicus australis Temm. Syrmaticus reevesi Gray. Talegallus cuvieri Less. Tetrao urogallus L. Tetraogallus altaicus Gebl. Tetraogallus himalayensis Gray. Tetrastes bonasia L. Thaumalea amherstiae Leadb. Thaumatea obscura Schl. Thaumalea picta L. Tragopan blythi Jerd. Tragopan caboti Gould. Tragopan menalocephala Gray. Tragopan satyra L. Tragopan temmincki Gray. Turnix pyrrhothorax Gould. T'ympanuchus americanus Reichenb.

\section{Nadere beschrijving van eenige veerpatronen bij Hoenderachtige Vogels.}

Bij de beschrijving der afzonderlijke veerpatronen, welke hier volgen gaat, is er geenszins naar volledigheid gestreefd. Deze zou slechts bereikt worden door een uitvoerige bespreking van alle veertypen bij alle hoenderachtige vogels. Een dergelijke bewerking van het materiaal behoort in een systematisch werk thuis. Deze verhandeling bedoelt dit niet te zijn en wil slechts aan de hand van enkele feiten op meer belangrijke veerverschijnselen wijzen. Voor de bespreking van een bepaald verschijnsel deed ik derhalve een keuze uit het mij ten dienste staande, veel rijkere materiaal. Op pag. 9 heb ik een lijst gegeven van de onderzochte hoenderachtige vogels.

De door mij onderzochte collectie hoenderachtige vogels was op lange na geen volledige. Vergelijkt men haar b. v. alleen voor zoover de geslachten betreft met de in den Catalogus van het Britsch Museum opgenoemde vormen b. v. bij de familie der Phasianidae, dan blijkt het, dat er van de daar genoemde 59 genera reeds 21 niet op mijn lijst voorkomen. Over de soorten behoef ik niet verder nit te weiden. Er bestaat dus groote waarschijnlijkheid, dat er belangrịjke feiten aan mij onbekend gebleven zijn. Enkele zeldzame vondsten, die ik na langere studie tusschen het toch inderdaad groote aantal onderzochte dieren aantrof, bevestigde dit vermoeden.

De voorbeelden, waarmede ik hier een algemeen geldende regel demonstreeren wil, zijn derhalve de toevallig voor mij best bereikbare gevallen. De meeste dier gevallen hadden bij deze beschrijving evengoed door een der tallooze andere voorbeelden, welke men vinden kan, vertegenwoordigd kunnen worden. De gekozen voorbeelden zijn dus volstrekt niet de voorbeelden, welke bij uitnemendheid een of ander conclusie rechtvaardigen. Slechts in heel enkele, duidelijk door mij aangeduide gevallen is dit wel zoo.

Ik heb ieder geval afzonderlijk en zoo kort mogelijk beschreven, terwijl ik de uit ieder geval getrokken conclusies telkens onder de beschrijving plaatste. In mijn opsomming der gemaakte conclusies vindt men deze allen weer opgenoemd, terwijl de samenvatting dezer conclusies in het overzicht is uitgewerkt.

Hier volgen dus de afzonderlyke beschrijvingen: 


\section{$\mathrm{N}^{0}$. 1. Numida meleagris var.}

De zadelveeren van het parelhoen vertoonen lichtgrijze dwarsbanden en vlekken op een donkergrijzen ondergrond. Verscheidene veeren vertoonen zeer duidelijk tegelijk banden en vlekken. De vlekken liggen niet slechts in dwarsrijen, maar vormen tegelijkertijd randstandige rijen.

Zie Pl. I. Fig. 6.

Conclusies:

$1^{0}$. Het blijkt, dat er samenhang bestaat tusschen vlekken en dwarsbanden. De banden lossen zich op in rijen van vlekken of wel, wat ik voor minder waarschijnlijk houd, de vlekken versmelten tot dwarsbanden.

$2^{0}$. De veer vertoont twee hoofdrichtingen van structuur:

a. Een dwarse structuur.

b. Een randstandige structuur.

\section{$\mathrm{N}^{0}$. 2. Acryllium vulturinum.}

De vleugeldekveeren van het Gier-parelhoen vertoonen of wel randstandige rijen van witte stippen, ò wel witte randstandige strepen op een zwarten ondergrond.

Sommige veeren vertoonen tegelijkertijd de rijen van witte stippen en de witte strepen. Dit is vooral dan interessant, wanneer een zelfde lijn ten deele door een witte streep, ten deele door witte stippen gevormd wordt.

Zie Pl. I. Fig. 10.

Conclusies:

$1^{\circ}$. Het blijkt, dat er samenhang bestaat tusschen stippen en randstandige strepen. Deze randstandige strepen lossen zich op in rijen van vlekken of stippen, of wel deze stippen versmelten tot randstandige rijen.

$2^{\circ}$. Het blijkt, dat het veerpatroon asymmetrisch worden kan zonder dat dit asymmetrie van den veervorm meebrengt.

$3^{0}$. Hieruit volgt, dat het veerpatroon niet bij uitsluiting een eigenschap van de veer is, maar dat het veerpatroon deel uitmaakt van een grooter complex.

$4^{0}$. Het blijkt, dat de schacht van de veer ten opzichte van het veerpatroon een merkwaardige lijn is, daar de schacht zich ten opzichte van linker en rechter vlaghelft der veer als een grenslijn voordoet.

5 . Het blijkt, dat rechter en linker vlaghelft ten opzichte van elkaar min of meer onafhankelijk zijn.

\section{$N^{0}$. 3. Thaumalea (hybr. obscura $\sigma^{\top} \times$ picta $ᄋ$ ).}

De borstveeren van deze door mijzelf gekweekte bastaard-hen vertoonen een groote verscheidenheid in de veerteekening. Men vindt tusschen een zijdelings gelegen flankveer en een centraal gelegen borstveer, welke ieder voor zich een eigen patroon vertoonen, allerlei overgangen. Deze overgangsteekeningen worden gedragen door naar den vorm symmetrisch gebouwde veeren, welke echter ieder een meer of minder asymmetrisch overgangspatroon vertoonen. Aldus:

De flankveer (a) draagt vijf witte dwarsbanden op zwarten ondergrond.

De middenstandige borstveer $(g)$ draagt twee zwarte randstandige banden op witten ondergrond.

Uit de figuur ziet men, dat langzamerhand de witte dwarsbanden breeder en breeder worden, totdat het wit tot ondergrond wordt (zie definitie) en vier zwarte dwarsbanden optreden. Deze dwarsbanden lossen zich op in min of meer nog aaneenhangende, in dwarse rijen gelegen vlekken. De vlekken richten zich echter niet slechts in dwarse richting maar ook in randstandige richting. Daar de vlekken echter steeds in verbinding blijven zoolang totdat 
ook een verbinding in randstandige richting heeft plaats gevonden, kan men feitelijk bij geen der veeren van echte vlekken spreken. Uit de oorspronkelijke vier dwarsbanden ontstaan ten slotte op deze wijze twee randstandige banden,

Zoowel de dwarse als de randstandige banden liggen bij de flankveer en de centrale borstveer ten opzichte van elkander, links en rechts van de veerschacht, volkomen symmetrisch.

Zie Pl. II. Fig. 1.

Conclusies:

$1^{0}$. Het blijkt, dat linker en rechter vlaghelft van een veer in aanleg gelijk zijn, maar dat zij toch onder zekere omstandigheden in staat zijn ten opzichte van elkaar een zekere zelfstandigheid te bewaren.

20. Het blijkt derhalve, dat de veerschacht een lijn van spiegelende symmetrie is.

$3^{0}$. Het blijkt, dat de veerteekening onafhankelijk van den veervorm asymmetrisch worden kan.

$4^{0}$. Het blijkt, dat randstandige en dwarse banden niet in dien zin gelijkwaardig zijn, dat zij door een eenvoudige groeiversnelling of -vertraging in elkaar omgevormd worden.

$5^{0}$. Randstandige en dwarse banden worden echter wel uit het zelfde materiaal opgebouwd, maar zij zijn daarom nog niet gelijkwaardige grootheden.

$6^{0}$. Het blijkt, dat het begrip ondergrond, dat bij definitie gesteld werd, slechts descriptieve waarde heeft.

7\%. Het blijkt; dat veeren van een zelfden vogel op de rij af genomen geleidelijke overgangen van patroon tot patroon vertoonen.

\section{$N^{0}$. 4. Argusianus grayi $\sigma^{7}$.}

Een losse, in de volière opgeraapte veer van den in "Artis" levenden Argusfazantenhaan, vertoont een fout in den veerbouw. In het midden is de veer n.l. in de richting loodrecht op de schacht ingedeukt. Het platte veervlak is daar als het ware plaatselijk ingedrukt. Bovendien zijn ter zelfder plaatse de veerranden naar de schacht toe ingesnoerd. Deze veer heeft dus geheel het voorkomen van een veer, welke tijdens haar groei een sterke storing heeft ondergaan. Behalve deze merkwaardigheid in den veerbouw draagt deze veer bovendien boven de insnoering een ander patroon dan onder deze insnoering. Deze beide patronen zijn door de insnoering scherp, dus niet geleidelijk, van elkander gescheiden. Ieder dezer beide patronen vindt men op zich zelf bij andere veeren terug. De patronen kunnen kort als volgt beschreven worden.

Het proximale patroon vertoont: in randstandige richting nitgerekte en min of meer in randstandige rijen gerangschikte, zwartbruine vlekken of ringvlekken (centrum lichtbruin) op lichten ondergrond.

Het basale patroon vertoont: grootere, in dwarse richting uitgerekte en min of meer in dwarsrijen gerangschikte, donkergrijze vlekken op lichten ondergrond.

Ik behoef nauwlijks op te merken, dat mij slechts één dergelijke veer bekend is geworden.

Zie Pl. I. Fig. \%.

Conclusies:

$1^{0}$. Het blijkt, dat met een storing in den veergroei een wijziging van het veerpatroon kan samengaan, dus beiden hoogstwaarschijnlijk als gevolgen van een zelfde oorzaak.

$2^{\circ}$. Het blijkt, dat een veerpapil in staat is een ander dan het eenmaal begonnen (dus normale) patroon op te bouwen.

$3^{0}$. Hieruit blijkt dus, dat deze beide op het oog zeer verschillende patronen inderdaad toch aan elkaar naverwant zijn, daar beide door een en het zelfde weefsel (dezelfde veerpapil) kunnen worden opgebouwd.

De veer, welke hier ter sprake kwam, kon ik ondanks een uitvoerig onderzoek aan een tiental geprepareerde huiden en opgezette vogels nergens terugvinden. Ook daarom heeft 
men derhalve het recht haar als abnormaal te beschouwen. Deze abnormaliteit doet echter aan hare belangrijkheid niets af. Immers door abnormaliteiten kunnen verborgen eigenschappen van levende weefsels aan het licht gebracht worden.

\section{$N^{0}$. 5. Pavo nigripennis $\sigma^{7}$.}

Het zadel der pauwen vertoont de bekende ocellus-dragende z.g. Pauwenstaartveeren. De middenstandige veeren van het zadel zijn volkomen symmetrisch van bouw, de meer naar de flank toe, dus zijstandige veeren zijn daarentegen asymmetrisch aldus: de buitenste vlaghelft dezer veeren draagt in hoofdzaak den ocellus, de rami van de buitenstandige vlaghelft zijn in veel grooter aantal aanwezig dan de rami der andere vlaghelft, ook zijn de eersten veel langer.

Een losse, in de volière opgeraapte veer van den Zwartvleugelpauw-haan vertoont een merkwaardige afwijking in den veerbouw. Deze afwijking, welke ik zoo dadelijk nader beschrijven zal, schijnt naar ik van een kenner vernam, wel een enkelen keer vaker voor te komen. $\mathrm{Mij}$ is echter slechts één exemplaar bekend, dat ik toevallig aantrof tusschen een groote collectie van wel een paar honderd pauwenveeren.

Van deze zadelveer vertoont slechts een zeer klein topgedeelte der rechter vlaghelft den bouw, de kleur en de teekening van den typischen ocellus. Het lijkt als 't ware alsof de rechter ocellushelft afgesneden is. Het grootste gedeelte van de rechter ocellushelft ontbreekt n.l., omdat de rami, welke haar moesten vormen, zeer kort zijn gebleven. Het aantal dezer rami is daarentegen aanmerkelijk veel grooter geworden dan normaliter het geval is, zoodat het aantal der rami rechts zich tot het aantal der rami links hier aan den top reeds verhouden als drie staat tot een. Halverwege de veer is deze verhouding afgenomen tot een van drie staat tot twee en aan den veervoet verhouden de aantallen der rami zich als drie staat tot drie. De hoogere rami ter rechter zijde dragen ter plaatse, waar de ocellus ophoudt, duidelijk eindstandige radii. De rami zijn dus niet afgebroken, zooals men in de figuur duidelijk zien kan. Lager gelegen rami dragen daarentegen geen eindstandige radii meer. Men vindt daar aan den top van elken ramus $\nabla$-vormig uiteenwijkende radii ten teeken, dat de ramus daar wel afgebroken is. Dit afbreken is vermoedelijk geschiedt in verband met de eenmaal aangegeven richting door de toppen der eerste niet afgebrokene rami. Dit is te meer waarschijnlijk daar men onder deze lager gelegen rami ook enkele niet afgebroken aantreft. Deze laatsten zijn juist zeer lang en wel ongeveer anderhalf maal langer dan de in spiegelbeeld gelegen rami der linker vlaghelft van dezelfde veer. Een dergelijke verhouding der rami onderling alsook ter linker en rechterzijde van de veerschacht is de typische voor zijstandige zadelveeren.

Nog een derde bijzonderheid moet worden opgemerkt aan deze veer namelijk dat aan den top, waar de rechts staande rami nog medewerken aan het vormen van den ocellus, vijf dezer rami met elkaar versmolten zijn.

Er kan dus geen twijfel bestaan of deze veer moet tijdens haar groei een belangrijke stoornis hebben ondergaan.

Zie Pl. II. Fig. 4 en $\%$.

Conclusies:

$1^{0}$. Uit de rechter veerhelft blijkt, dat de veerpapil in staat is aan den veertop een ander patroon te ontwikkelen, dat dus eigen is aan een andere plaats van het lichaam, dan aan de lager gelegen deelen van dezelfde veer.

$2^{0}$. Uit de vergelijking van rechter met linker veerhelft blijkt, dat de zelfstandigheid der vlaghelften ten opzichte van elkaar nog zoo groot zijn kan, dat elke vlaghelft voor zich een ander veertype kan vertegenwoordigen. Dit verschijnsel is dus een geheel ander dan het regelmatig optredende verschijnsel (bijv. bij vele Phasianus staartslagpennen) van asymmetrie der vlaghelften eener zelfde veer ten opzichte van elkander. Vertoont dus plaats $A$ van het vogellichaam het patroon $a$ en plaats $B$ van 
dezelfden vogel het patroon $b$, dan is het nu uit deze veer gebleken, dat bij wijze van abnormaliteit een zelfde veer zoowel het patroon $a$ als het patroon $b$ kan vertoonen. In het onder $\mathrm{N}^{0} .4$ bedoelde geval vertoonde de veertop patroon $a$, de veervoet patroon $b$; in het hier bedoelde geval vertoont de linker vlaghelft patroon $a$ en de rechter vlaghelft patroon $b$, althans op het topgedeelte na.

\section{$N^{0}$. 6. Polyplectron chinquis $\sigma^{\top}$.}

De Spiegelpauw-haan vertoont ocelli op de volgende plaatsen van het lichaam:

a. Over de schacht heengrijpende, ongepaarde ocelli op rug, schouder, vleugeldek, remiges secundarii. De ocelli staan volkomen eindstandig, de schacht eindigt dus in den ocellus.

b. Niet over de schacht heengrijpende, gepaarde ocelli op bovenstaartdek en staart. Deze ocelli staan niet eindstandig, de schacht loopt nog verder naar voren tusschen de beide ocelli door.

De ocellus bestaat hier uit de volgende onderdeelen:

Centrum: groot, rond, metaalglanzend, donkergroen tot violet verkleurende naar gelang van den inval der lichtstralen.

Eerste ring: zwart.

Tweede ring: grijs.

Derde ring: helder wit. Déze ring is slechts ten deele en niet overal ontwikkeld.

Beschouwt men enkele der remiges secundarii en enkele van de veeren van het vleugeldek nauwkeuriger, dan blijkt het ten duidelijkste dat de ongepaarde oogvlek uit twee centra is samengesteld. De ringhelften sluiten aan den onderkant van den ocellus, nabij de schacht niet meer aaneen, doch verspringen ten opzichte van elkaar; of wel bij een heel enkele veer sluiten zich de ringhelften van iedere vlaghelft tot zelfstandige ringen. De figuren verduidelijken deze beschrijving.

Zie Pl. III. Fig. 7 en 8.

Conclusies:

$1^{0}$. Het blijkt, dat hier de ongepaarde ocelli inderdaad dubbele over de schacht heengrijpende ocelli zijn.

$2^{0}$. Uit het verspringen der ocellushelften ten opzichte van elkaar bij een veer blijkt het, dat ieder der vlaghelften een zekere zelfstandigheid heeft behouden.

$3^{0}$. Uit het voorkomen van slechts zeer weinige veeren, welke het verspringen dezer ocellushelften vertoonen, volgt, dat de beide vlaghelften in principe volkomen symmetrisch aangelegd zijn. Immers men vindt dit verspringen ook slechts bij veeren, welke tevens asymmetrisch van bouw zijn.

$4^{n}$. In het "verspringen" gedragen zich de ocellushelften volkomen als dwarsbanden.

$5^{0}$. Daar ocelli stellig niet een primitieve figuur voorstellen, en de ongepaarde ocelli geheel eindstandig op de veer liggen, blijkt het, dat de veertop een niet primitief patroon kan dragen.

$6^{\circ}$. Daar de ongepaarde zoowel als de gepaarde ocelli uit 2 centra zijn samengesteld, is het hoost waarschijnlijk, dat men in beide gevallen met een identiek gelijke figuur te doen heeft.

ro. Uit $6^{\circ}$. volgt derhalve, dat het patroon van een bepaald veerdeel (den top b. v.) niet zonder meer vergeleken mag worden met het zelfde veerdeel (den top b. v.) bij een andere veer. De veerpatronen verplaatsen zich klaarblijkelijk ten opzichte van de veer.

$8^{\circ}$. Hieruit volgt dus, dat men de dubbele ocelli van den Spiegelpauw-haan, welke niet eindstandig op de veer liggen, waarschijnlijk wel vergelijken mag met de ongepaarde, wel aan den veertop gelegen ocelli van den Pauwenhaan. Hiervoor pleit nog een ander argument, zie $\mathrm{N}^{0} .9$, namelijk dat de Pauw-ocellus niet één, maar twee centra bezit. 


\section{$\mathrm{N}^{0}$. 7. Meleagris americana $\sigma^{7}$ en Meleagris ocellata $\sigma^{7}$.}

De wilde Kalkoen vertoont op de staartpennen een eindstandig wit veild, waaraan een breede, zwarte dwarsband grenst. Op het midden van dezen band bevindt zich een grootere of kleinere, in dwarse richting uitgerekte glansvlek. Het zelfde treft men aan bij de onderstaart-dekveeren doch in andere verhoudingen. Hier zijn de glansvlekken de relatief het sterkst ontwikkelde figuren. Deze onderstaart-dekveeren schijnen derhalve een veerstadium te vertoonen, dat onmiddellijk aan dat der ocellus-dragende veeren voorafgaat. Vergelijkt men deze veeren met de staartpennen van Meleagris ocellata $\sigma^{7}$, op wiens bestaan ik eerst door de voorgaande beschouwingen opmerkzaam werd, dan wordt deze opvatting daardoor geheel bevestigd. Vooral de middelste staartpennen dezer laatste soort vertoonen door de afronding der zwarte dwarsbanden en der glansvlekken, welke zich tot centra vormen, min of meer afgeronde oogvlekken ter linker en rechter zijde van de schacht. Bij de staartpennen van Meleagris americana vormt de op den zwarten dwarsband gelegen glansband samen met dezen een complexen of samengestelden band.

Men krijgt dus den indruk, dat de onderstaart-dekveeren hier het meest gespecialiseerde, dus het minst primitieve patroon dragen. Immers deze veeren sluiten het beste aan, wat hun patroon betreft, bij de zoogenaamde oogveeren van Meleagris ocellata, welke zeer zeker een niet primitief karakter dragen. Hieruit zou men dus allicht de conclusie kunnen trekken, dat onderstaait-dekveeren een zeer vooruitstrevend karakter vertoonen. Verderop zal het echter by Tragopan melanocephalus $\sigma^{7}$ blijken, (zie $\mathrm{N}^{0}$. 19) dat men daar juist aan deze onderstaart-dekveeren een primitief karakter moet toekennen.

Zie Pl. III. Fig. 2 en 3.

Conclusies:

$1^{0}$. Het blijkt, dat er tusschen oogvlekken en complexe dwarsbanden een nauw phylogenetisch verband kan bestaan.

$2^{0}$. Dit wordt bevestigd, door het meestal nauwkeurig samentreffen zoowel als door het bij asymmetrische veeren „verspringen" der gepaarde ocelli, der ongepaarde ocellushelften, en der complexe dwarsbanden.

$\mathbf{3}^{0}$. Het blijkt, dat een zelfde veerveld (hier onderstaart-dekveeren) bij een zelfde groep van vogels somtijds primitief, somtijds (bij een andere soort n.l.) secundair gewijzigd is.

$4^{0}$. Hieruit volgt dus, dat Ermer's wet aangaande de postero-anteriore ontwikkeling geen algemeene geldigheid heeft.

$5^{0}$. Het blijkt, dat op meestal aan het oog onttrokken plaatsen van het lichaam zeer goed secundair sterk gewijzigde veeren kunnen optreden. Deze opmerking bestrijdt dus de meer gangbare meening, welke aan de selectie-theorie van DARwiN ontleend wordt.

\section{$N^{0}$. 8. Pavo nigripennis $\sigma^{7}$.}

Bij zijstandige zadelveeren van den Pauwhaan vindt men soms veeren, welke duidelijker, soms minder duidelijk slechts op een vlaghelft een ocellus vertoonen. In dit geval is de ocellus geheel afgerond.

Zie Pl. II. Fig. 2.

Conclusies:

$4^{0}$. Het blijkt, dat het zoogenaamde pauwenoog uit twee centra opgebouwd is, waarvan het een geheel verloren kan gaan, zonder dat daarmede ook het tweede verdwijnt.

$2^{0}$. Het blijkt, dat een sterk asymmetrische veervorm met een asymmetrisch patroon gepaard kan gaan.

$3^{0}$. enz. Verdere conclusies als bij No. 9, Pavo cristatus.

\section{No. 9. Pavo cristatus $\sigma^{\top}$.}

Het normale Pauwenoog, dat op den z.g. pauwenstaart d.w.z. dus op de verlengde zadelveeren gelegen is, bestaat uit de volgende onderdeelen: 
Centrum: donkerblauw, aan den onderkant (basis) min of meer wigvormig uitgesneden. Eerste ring: groen.

Tweede ring: bruin.

Derde ring: groen.

Vierde ring: paars.

Het donkerblauwe centrum ontbreekt bij de meest-staartwaarts gelegen veeren, zoodat bij deze veeren de eerste ring tot centrum wordt, hetwelk dus groen ziet.

Een enkele maal vindt men een veer, welke wel is waar een enkele oogvlek of ocellus draagt, maar deze ocellus vertoont twee duidelijk gescheiden centra. Soms ook is de ocellus uit twee ongelijke, „verspringende" helften samengesteld. Ook bij dergelijke veeren kan al dan niet het blauwe centrum ontbreken en geheel vervangen zijn door den eersten groenen ring. De figuur vertoont een dergelijken ocellus met twee centra.

Zie Pl. II. Fig. 5.

Conclusies:

$1^{\circ}$. Het blijkt, dat zelfs bij een zeer gespecialiseerde veer, als bijv. de pauwenveer, elke vlaghelft nog een zekere mate van zelfstandigheid bezitten kan.

$2^{\circ}$. Het blijkt, dat het ongepaarde pauwenoog inderdaad een over de schacht grijpende, dubbele oogvlek is.

$3^{\circ}$. In verband met het bij Maleagris americana $\sigma^{7} \mathrm{~N}^{0} .7$ gezegde mag men aannemen, dat het pauwenoog is ontstaan uit complexe dwarsbanden. Vergelijk ook $\mathrm{N}^{0} .21$.

$4^{0}$. Bij de wijziging van complexe dwarsband tot ocellus is de teekening beperkt geworden tot een tegen de schacht aan gelegen strook. Deze strook vindt men ool bij andere ocelli terug: Polyplectron, Argusianus e. a.

Over het zeldzame voorkomen van een dergelijke veer, als hier beschreven werd, bij pauw-hanen kan ik nog een en ander mededeelen. Ik vond een dergelijke veer steeds gepaard, dus een ter linker en een ter rechter zijde van het zadel, en wel bij vijf exemplaren. Twee dezer exemplaren leven nog in "Artis". Tot nu toe ontbrak mij de gelegenheid om na te gaan of deze vogels ieder jaar twee dergelijke veeren voortbrengen en of men dit verschijnsel misschien als een ouderdomsverschijnsel moet opvatten. In ieder geval blijkt uit het hierboven gezegde, dat men een twee centra-dragende pauwenveer waarschijnlijk niet als abnormaliteit moet beschouwen. Ik trof een dergelijke dubbelen-ocellus dragende veer zoowel bij $P$. cristatus $\sigma^{\top}$ als bij $P$. nigripennis $\sigma^{\top}$ en $P$. muticus $\sigma^{\top}$ aan. Deze afwijking treedt dus vrij geregeld op.

\section{$N^{0} .10$. Argusianus grayi $\sigma^{r}$.}

De top der zadelveeren van den Argus-haan vertoont aan weerszijden van de schacht vele uitgerekte, donkerbruine vlekken op een lichten ondergrond. Enkele dezer vlekken hebben een lichter bruin centrum en zijn dus ringvlekken. Daar de vlekken met enkele of complexe banden, welke dwars op de schacht verloopen, samenhangen, passen zij ook bij de schacht volkomen tegen elkaar aan, indien men zuiver symmetrische veeren beschouwt. Sommige dier vlekken behouden daarbij hunne zelfstandigheid als vlek voor zooverre zij n.l. verderaf, andere daarentegen versmelten ten deele of geheel met hun spiegelbeeldvlekken op de andere vlaghelft voor zooverre zij dichterbij of izelfs op "de schacht ontstaan zijn. In dat geval vormen zij dubbele, over de schacht heengrijpende, ongepaarde ringvlekken. Deze ringvlekken gelijken volkomen op een pauwen-ocellus in het klein.

Zie Pl. II. Fig. 8.

Conclusies:

$\mathbf{1}^{0}$. Het blijkt, dat dwarsrijen van ringvlekken met complexe dwarsbanden ten nauwste kunnen samenhangen.

$2^{0}$. Het blijkt, dat dubbele, over de schacht heengrijpende ringvlekken met dwarsbanden kunnen samenhangen. 
$\mathbf{3}^{0}$. Daar deze ringvlekken zich principieel in niets van ocelli onderscheiden, volgt hieruit, dat er een verband bestaan kan tusschen ocelli en complexe dwarsbanden.

\section{NN. 11. Gallus aeneus $\sigma^{7}$.}

Tusschen de zadelveeren van dezen haan treft men veeren aan, welke weliswaar een geheel zwart gepigmenteerden top bezitten, maar waarbij dit zwarte pigment niet geheel en al gedekt wordt door de metaalglans-kleur. Deze veeren dragen gepaarde glansvlekken of wel glansdwarsbanden op zwarten ondergrond.

Bij de meeste veeren vindt men bij alle vogels, dat de glansvlekken geheel samenvallen met het omliggende pigment. Daar de structuurkleur, waarop immers de metaalglans berust, slechts boven een donker gepigmenteerden ondergrond voor het bloote oog zichtbaar wordt (zie GaDow), is het meestentijds slechts onder den microscoop uit te maken of de glansvlekken ook buiten het pigment optreden, of wel dat de glansstructuur geheel van het pigment afhangt en er als het ware door beperkt wordt. In het hier beschreven geval blijkt het duidelijk, dat dit niet het geval is.

Zie Pl. I. Fig. 11.

Conclusies:

$1^{0}$. Het blijkt, dat de inwendige veerstructuur, welke den metaalglans veroorzaakt, geheel onafhankelijk van de daaronder liggende pigmentatie ook in dwarsbanden of gepaarde vlekken kan optreden.

$2^{0}$. Het blijkt, dat metaalglans en pigmentatie, wat het patroon betreft, aan dezelfde regels onderworpen zijn.

$3^{0}$. Het ligt voor de hand te vermoeden, daar vaak metaalglans de pigmentteekening dekt, dat beide kleuruitingen toch door een zelfde gegeven worden beheerscht.

\section{No. 12. Polyplectron chinquis .}

De halsveeren van de vrouwlijke Spiegelpauw vertoonen witte dwarsbanden op zwarten ondergrond. Deze witte of lichte dwarsbanden zijn vaak met zwarte vlekken en stippen bedekt. Het zwart van den ondergrond doet zich dus, gelijk van zelf spreekt, ook als banden voor. In den op een na meest eindstandigen, zwarten band treedt er concentratie op van het zwarte pigment en wel tegen de veerschacht aan. Deze concentratie van zwart pigment is op volkomen dezelfde plaats gelegen, als waar zoowel bij den haan als bij de hen op andere veeren de ocellus optreedt.

Zie Pl. III. Fig. $6 a$.

Conclusies:

$1^{0}$. Het blijkt, dat bij de(n) Spiegelpauw de ocellus en de zwarte dwarsband met elkaar verband houden.

$2^{\circ}$. Daar een ocellus ingewikkelder structuur vertoont dan een dwarsband, mag men in verband met het bovenstaande aannemen, dat de ocellus afgeleid moet worden van den dwarsband. Dit is te meer waarschijnlijk, omdat men juist bij hennen (misschien ook bij jonge hanen) zwarte dwarsbanden aantreft, waar elders ocelli liggen.

$3^{\circ}$. Bij de wijziging van dwarsband tot ocellus is de teekening beperkt geworden tot een tegen de schacht aan gelegen strook. Vergelijk $\mathrm{N}^{0} .9$.

\section{$N^{0}$. 13. Polyplectron bicalcaratum $\overbrace{}^{7}$ en $\sigma^{7}$.}

De staartveeren van deze vrouwlijke Spiegelpauw vertoonen slechts op één vlaghelft een ocellus-achtige vlek. Het middelste paar staartveeren echter vertoont op beide vlaghelften deze ocellus-achtige vlekken. Het zelfde geldt voor de hanen, welke echte ocelli dragen. De plaats op de linker vlaghelft, welke door deze ocellus-achtige vlek ingenomen wordt, correspondeert op de rechter vlaghelft met twee zwarte dwarsbanden. Het schijnt derhalve, dat deze vlek, behalve de plaats der beide zwarte dwarsbanden tevens die van den daartusschen gelegen, witten band in beslag neemt. Ook hier behoort evenals bij $\mathrm{N}^{0} .12$ de zwarte dwarsband feitelijk 
als ondergrond beschreven te worden. Daar deze banden echter met ocelli samenhangen, meende ik hen als teekening te moeten beschrijven.

Een dergelịjke versmelting van een hooger gelegen met een lager gelegen dwarsband treft men vaak bij Phasianus-soorten aan. Dit verschijnsel is dus juist het omgekeerde van dat der complexe dwarsbanden. Bij complexe dwarsbanden wordt door latere differentiatie één band tot twee banden, terwijl men hier juist twee banden tot één ziet worden. Het feit, dat de beide bandgrenzen (1 en 2) ter eener zijde van de veer correspondeeren met de buitengrenzen ( 1 en 2$)$ van twee banden ter andere zijde wijst $\mathrm{m}$. i. voldoende op het bestaan eener versmelting of samenvoeging. De grenzen aan de boven- en aan de onderzijde van de ocellus-achtige vlek zijn dus volkomen vergelijkbaar met de bovenste en onderste grenzen van de twee zwarte dwarsbanden. De versmelting kan men zich ook aldus voorstellen, dat de tusschen gelegen witte dwarsband niet tot ontwikkeling gekomen is. Dit laatste pleit weer voor de opvatting, dat het zwarte pigment wel degelijk den ondergrond en niet de teekening voorstelt. Voor beide opvattingen (versmelting en verdwijnen van den witten band) valt evenveel te zeggen, ik wil daarin dus geen beslissing nemen.

Zie Pl. III. Fig. 5 en $6 b$ en tekstfig. 1.

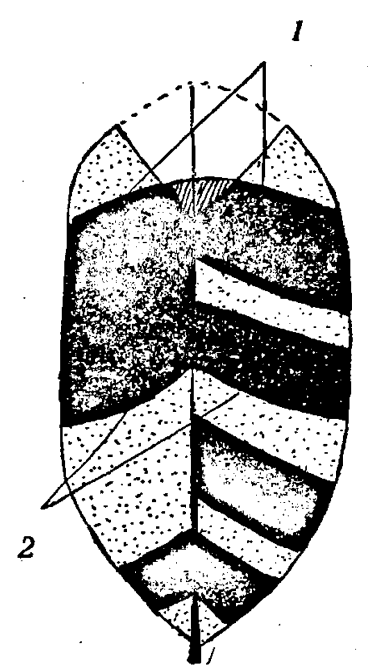

Fig. 1. Staartpen. Polyplectron bicalcaratum 오. Het door de stippellijn afgesloten witte en het gestreepte gedeelte der veer

Conclusies :

$1^{0}$. Het blijkt, dat er tusschen dwarsband en ocellus samenhang bestaat.

$2^{0}$. Het blijkt, dat men ocelli onderling zonder meer niet met elkaar vergelijken mag, daar sommigen met één dwarsband samenhangen anderen met twee.

$3^{0}$. Het blijkt, dat onder invloed van de lichaamssymmetrie ook normaliter veeren ontstaan met een asymmetrisch patroon. (Men vergelijke Bond's merkwaardige opvatting over hermaphroditisme bịj één veer).

$4^{0}$. Het blijkt, dat bij een zelfde veer de eene vlaghelft een phylogenetisch jonger stadium kan vertegenwoordigen (dwarsband) dan de andere vlaghelft dier zelfde veer (ocellus).

$5^{0}$. Het blijkt, dat de asymmetrie eener veer onder $3^{0}$ en $4^{0}$ bedoeld volstrekt niet op hermaphroditisme behoeft te berusten (bij mijn weten doet ze dat nooit).

$6^{0}$. Het blijkt, dat het begrip ondergrond, dat bij definitie gesteld werd, slechts descriptieve waarde heeft, en dat men in dit speciale geval met evenveel waarschijnlijkheid betoogen kan, dat de lichte zoowel als de donkere kleur de teekening voorstelt.

Ook bij de manlijke Spiegelpauwen vindt men bij enkele soorten op de staartveeren een éénzijjdigen, dus op één vlaghelft gelegen ocellus (b.v. $\mathrm{N}^{0} .17$ Polyplectron bicalcaratum $\sigma^{7}$ ). Dit wil daarom volstrekt niet zeggen, dat de vlaghelft, welke geen ocellus draagt, daarom een vrouwelijk patroon zou vertoonen. Ik kom hierop nader terug.

\section{$N^{0}$. 14. Gennaeus lineatus $\sigma^{7}$.}

Vervolgt men tusschen nek en buik van den manlijken Gestreepten-fazant de veeren rug-buikwaarts, dan treft men achtereenvolgens de volgende toestanden op de linker flank van het dier aan:

a. Eerste veer (Rugveer): Beide vlaghelften dragen vijf randstandige, zwarte strepen op witten ondergrond.

b. Tweede veer: De zwarte strepen der rechter vlaghelft zijn meer onduidelijk en verloopen zigzagsgewijs. De witte ondergrond neemt de overhand. Linker vlaghelft als bij eerste veer. 
c. Derde veer: De zwarte strepen der rechter vlaghelft zijn op enkele stipjes na ver-: dwenen. De buitenrand van de rechter vlaghelft is geheel zwart, zoodat deze vlagzijde half wit half zwart is. Linker vlaghelft in hoofdzaak als bij eerste veer, echter verloopen de strepen er zigzagsgewijs.

d. Vierde veer: De zwarte strepen der rechter vlaghelft zijn geheel verdwenen, ook is het wit daar ter plaatse verdwenen, zoodat de rechter vlaghelft nu geheel zwart ziet. De zwarte strepen der linker vlaghelft zijn onduidelijk. De witte ondergrond heeft daar de overhand. De veerschacht is wit.

e. Vijfde veer: De rechter vlaghelft is zwart. De linker vlaghelft is geheel als de rechter vlaghelft van de derde veer. De schacht is zwart.

$f$. Zesde veer: Beide vlaghelften zijn zwart, slechts aan de linker zijde van de schacht verloopt nog een fijne, witte, overlangsche streep. De schacht is zwart.

$g$. Zevende veer (Buikveer): De beide vlaghelften zijn evenals de schacht geheel zwart.

Zie Pl. III. Fig. 4 en tekstfig. 2.

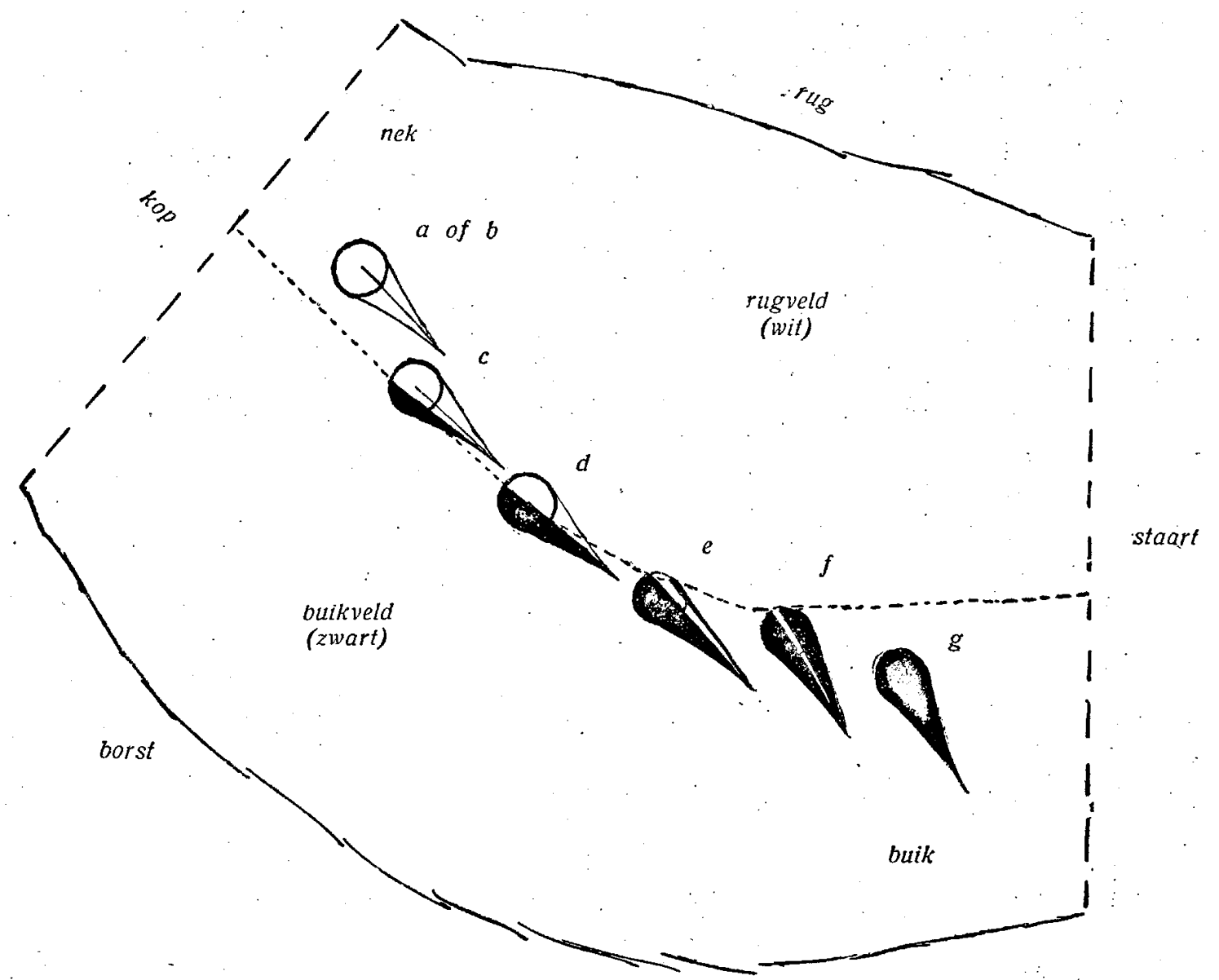

Fig. 2. - Plaatsing der veeren $a-g$ op den romp van den vogel.

De stand der veeren komt met den natuurlijken stand op het lichaam overeen. Gennaeus lineatus $\sigma^{\top}$.

De cirkel $\bigcirc$ stelt de veerpapil voor, de daaraan geteekende spitse figuur verbeeldt de veervlag, op wier midden de schacht als een rechte streep aangegeven staat. De letters zijn dezelfde als in den tekst en op Pl. III. Fig. 4.

Conclusies:

$1^{\circ}$. Het blijkt, dat er tusschen rug- en buikveer, ieder als vertegenwoordiger gekozen van een veerveld, min of meer geleidelijke overgangsvormen bestaan.

$2^{\circ}$. Het blijkt, dat de scheiding tusschen twee veerpatronen onafhankelijk is van de individualiteit der veeren. Deze scheiding kan midden door een veer heenloopen.

$3^{0}$. Hieruit volgt derhalve, dat deze scheidingsveeren geen typisch eigen patroon dragen, 
maar het patroon van het veerveld of van de veervelden; waaraan zij overeenkomstig hun plaatsing op het lichaam mede deeluitmaken, vertoonen.

$4^{0}$. Het blijkt, dat eenzelfde veerpapil, ondanks het feit, dat rug- en buikveer geheel verschillend zijn, tegelijkertijd zoowel het eene als het andere patroon kan voortbrengen.

$5^{\circ}$. De zeven hierboven beschreven veeren wijzen dus niet op een verwantschap in patroon tusschen het rug- en het buikveld, daar door de toevallige plaatsing der veerpapil haar eene gedeelte in het rug-, haar andere gedeelte in het buikreld ontstond. Men moet derhalve bij patronen van een zelfde veer, welke volgens een lijn evenwijdig aan de schacht van elkaar gescheiden zijn, uiterst voorzichtig zijn met het trekken van conclusies aangaande hun onderlinge verwantschap. Dit is niet het geval bij patronen, welke door een scherpe grenslijn loodrecht op de schacht van elkaar gescheiden zijn, daar immers in dat geval zonder twijfel hetzelfde papilweefsel beide patronen deed ontstaan (zie Argusianus No. 4 en Pavo No. 5).

$6^{\circ}$. Het blijkt uit de vijfde $(e)$ en zesde $(f)$ veer, dat de overlangsche strepen kunnen ontstaan door samentreffen van twee veerpatronen op een veer.

$7^{\circ}$. Het blijkt, dat men overlangsche strepen op veeren van verschillende vogelsoorten niet zonder nader onderzoek met elkaar mag vergelijken, daar zij op zeer verschillende wijzen kunnen ontstaan (zie Syrmaticus reevesi $\mathrm{N}^{0} .2^{\%}$ ). Het begrip overlangsche streep heeft slechts descriptieve waarde.

\section{No. 15. Acryllium vulturinum.}

De naar den kop toe gelegen zadelveeren van het Gier-parelhoen vertoonen een zeer fijne dwarsstreping van witte strepen op donkeren ondergrond. De veeren midden op den rug dragen echter een teekening van witte, in dwarsrijen gelegen stippen. Deze stippen liggen in de richting en als het ware in het verlengde van de witte strepen en onderbreken deze derhalve. De stippen zijn bovendien tegelijkertijd gerangschikt in duidelijke randstandige rijen en in dwarsrijen, overeenkomstig haar verband met de witte dwarsstrepen. Tegelijkertijd en vermoedelijk in verband met deze stipontwikkeling wijzigt zich het strepenpatroon geleidelijk tot zeshoekige, celachtige figuren. Een nog meer naar den staart toe gelegen veer vertoont de witte stippen, welke ook hier nog in de rijen liggen, welke bij de vorige veer door witte strepen werden vertegenwoordigd. Van deze witte strepen is geen spoor meer te bekennen bij de achter op het zadel gelegen veeren, welke de zeshoekige, celachtige figuren in volkomen ontwikkeling vertoonen.

Zie Pl. I. Fig. 9.

Conclusies:

$1^{0}$. Het blijkt, dat er samenhang bestaat tusschen witte dwarsstrepen en de witte in dwarsrijen gelegen stippen.

$2^{0}$. Het blijkt, dat er samenhang bestaat tusschen dwarsstrepen en zeshoekige, celachtige figuren.

$3^{0}$. De veer vertoont twee hoofdrichtingen van structuur:

a. Een dwarse structuur.

$b$. Een randstandige structuur.

$4^{0}$. Het blijkt in verband met $N^{0} .2$, dat randstandige en dwarse banden niet in dien zin gelijkwaardig zijn, dat zij door een eenvoudige groeiversnelling of -vertraging in elkaar omgevormd worden.

$5^{0}$. Randstandige en dwarse banden worden echter wel uit hetzelfde materiaal opgebouwd, maar zij zijn daarom nog niet gelijkwaardige grootheden.

\section{$N^{0}$. 16. Thaumalea $\delta^{\pi} \sigma^{7}$.}

De middelste kraagveeren van Thaumalea picta $\sigma^{7}$ onderscheiden zich van de middelste kraagveeren van Thaumalea amherstiae ơ bij de volwassen dieren in drieërlei opzicht:

a. De kraagveer van $T$. picta is oranje.

De kraagveer van $T$. amherstiae is wit. 
b. De kraagveer van $T$. picta eindigt boogvormig.

De kraagveer van $T$. amherstiae eindigt cirkelrond.

c. De kraagveer van $T$. picta heeft een randstandigen band en een dwarsband, welke beiden tot den veerrand toe verloopen.

De kraagveer van $T$. amherstiae heeft een randstandigen band en een dwarsband, waarvan de dwarsband niet, de randstandige band wel tot den veerrand toe verloopen.

Een bastaard-haan, welken ik kweekte uit een $T$. picta-haan en een $T$. amherstiae-hen, onderscheidt zich door zijn middelste kraagveeren aldus:

a. De kraagveer van $T$. hybr. is wit.

b. De kraagveer van $T$. hybr. eindigt boogvormig.

c. De kraagveer van $T$. hybr. heeft een randstandigen band en een dwarsband, waarvan de dwarsband niet, de randstandige band wel tot den veerrand toe verloopen.

Zie Pl. III. Fig 11.

Conclusies:

$1^{0}$. Het blijkt, dat veervorm en veerkleur onafhankelijk van elkaar overerfbaar zijn.

$2^{\circ}$. Het blijkt, dat veervorm en veerteekening onafhankelijk van elkaar overerfbaar zijn.

$3^{\circ}$. Het blijkt, dat veerkleur en veerteekening onafhankelijk van elkaar overerfbaar zijn.

$4^{0}$. Het blijkt, dat men patronen van verschillende kleuren met elkaar vergelijken mag.

\section{$N^{0} .17$. Tragopan satyra $\sigma^{7}$.}

Vervolgt men bij den volwassen haan van het Saterhoen langs de middellijn van den rug de veeren kop-staartwaarts, dan treft men de volgende patronen aan:

a. Eerste veer (Kopveer): Geheel zwart.

b. Tweede veer: Zwart, doch aan den top rood. Daar de veer van mijn afbeelding niet geheel op de middellijn lag, is dit rood asymmetrisch ontwikkeld.

c. Derde veer (Nekveer): Geheel rood, met zeer kleine, witte, eindstandige, ongepaarde, op de schacht gelegen vlek.

d. Vierde veer: Als derde, doch witte vlek grooter en door zwart pigment omgeven.

e. Vijfde veer: Als vierde, doch basale gedeelte der veer zwart gepigmenteerd, en witte vlek duidelijker.

$f$. Zesde veer: Als vijfde, doch basaal gedeelte der veer grooter en met onregelmatige, scheef gestelde, witte dwarbanden.

g. Zevende veer (Zadelveer): Het zwarte pigment is in verbinding getreden met het zwart, dat om de witte vlek gelegen is. Hierdoor is het roode gedeelte van de veer in twee randstandige vlekken (een op iedere vlaghelft) gescheiden. Al het zwarte pigment, ook het om de witte vlek heen gelegene, draagt witte, scheef gestelde dwarsbanden.

h. Achtste veer: Als zevende, maar het zwarte pigment is nog meer ontwikkeld, zoodat de roode vlekken veel kleiner zijn. De roode, randstandige vlek op de rechter vlaghelft is ten deele bruin gekleurd.

i. Negende veer: Als achtste, doch met nog sterker ontwikkeling van het zwarte pigment, dat aàn den veerrand de roode (of bruine) vlekken omvat.

$j$. Tiende veer: Als negende, doch de roode (bruine) vlekken nu geheel in het zwarte pigment ingesloten.

Deze veeren vertoonen slechts enkele typen van de tallooze overgangsvormen, welke men tusschen de eerste $(a)$ en tiende $(j)$ veer op het vogellichaam aantreft. Zie Pl. I. Fig. 1.

Conclusies:

$1^{0}$. Het blijkt, dat er tusschen kop- en zadelveer, ieder als vertegenwoordiger gekozen van een veerveld, min of meer geleidelijke overgangsvormen bestaan.

$2^{0}$. Het blijkt, dat het begrip ondergrond slechts descriptieve waarde heeft, daar b.v. het rood bij de nekveer ondergrond is, doch bij de zadelveer als teekening beschre ven moest worden. 
$3^{\circ}$. Het blijkt, dat men patronen van verschillende kleur met elkaar vergelijken mag, daar het rood van de zelfde randstandige vlekken soms door bruin vervangen wordt.

$4^{0}$. Het blijkt, dat kop-, nek- en zadelpatroon feitelijk geen scherp gescheiden patronen zijn, doch beschouwd moeten worden als variaties van hetzelfde patroon. Deze drie patronen zijn dus ten nauwste aan elkaar verwant.

$5^{0}$. In verband met $\mathrm{N}^{0} .14$ blijkt het, dat er een principieel ander verschil bestaat tusschen nekveld en buikveld eenerzijds en tusschen nekveld en zadelveld anderzijds. In het eerste geval is de verwantschap veel geringer dan in het laatste. Hieruit volgt dus, dat niet alle grenzen, welke men met het bloote oog tusschen verschillende veervelden ziet, dezelfde waarde hebben.

\section{$N^{0}$. 18. Tragopan satyra $\sigma^{\circ}$ en $q$.}

Geheel dezelfde bruine of roode, min of meer randstandige, gepaarde vlekken als bedoeld in het vorig nummer, $\mathrm{N}^{0} .1 \%$, bij de zevende, achtste, negende en tiende veer, vindt men ook terug bij de vleugeldekveer van den volwassen, manlijken vogel $(b)$. Deze zijvlekken hebben hier soms wel, soms niet een zwarten ring. Bij een vrouwlijke volwassen vogel $(a)$ vindt men deze vlekken vertegenwoordigd door een breeden, donker-zwarten dwarsband.

Zie Pl. I. Fig. 3.

Conclusies:

$\mathbf{1}^{\circ}$. Het blijkt, dat deze gepaarde zijvlekken met een dwarsbandteekening samenhangen.

$2^{0}$. Het blijkt, dat deze typische dwarsbandteekening, welke op eenigen afstand van den veertop gelegen is, een plaats aangeeft of inneemt van latere differentiatie. Men vergelijke hiermede de ocelli bij Polyplectron en Pavo.

\section{No. 19. Tragopan melanocephalus $\sigma^{7}$.}

Het geslacht Tragopan is gekenmerkt door een zeer typische, parelvormige, witte, ongepaarde, eindstandige, over de schacht heengrijpende vlek. Deze parelvlek treedt op zoowel bij hanen als bij hennen en wel op de meeste veeren over het geheele lichaam. Zij is over het algemeen zeer typisch en constant van vorm. Men vindt haar reeds afgebeeld in Pl. I. Fig. 1. en Pl. I. Fig. 4. Slechts na langere studie trof ik deze vlek als dwarsband aan.

Enkele staartonderdekveeren van den haan van dit Saterhoen vertoonen een verbreeding bij de witte parelvormige vlek. Men vindt deze vlek bij eenige veeren als een witte dwarsband terug, bij andere veeren ziet men, dat de linker en rechter vlekhelft langs de schacht ten opzichte van elkaar "verspringen". In dit opzicht gedraagt zich de vlek dus geheel als een ocellus van Pavo en Polyplectron. Ook is deze vlek soms van onderen wigvormig ingesneden, geheel overeenkomstig aan de wigvormige insnijding van het blauwe centrum van den Pavoocellus. De hier bedoelde, in dwarse richting gestrekte vervorming der parelvormige vlek is mij alleen bekend bij den haan van deze soort en wel uitsluitend bij de staartonderdekveeren. Ik vond haar nooit als abnormaliteit bij de andere door mij onderzochte soorten.

Zie Pl. I. Fig. 2.

Conclusies :

$1^{\circ}$. Het blijkt, dat de witte parelvormige vlek van het Saterhoen met een dwarsbandteekening samenhangt.

$2^{\circ}$. Het blijkt, dat deze ongepaarde vlek inderdaad een dubbele, over de schacht heengrijpende vlek is.

$3^{\circ}$. Uit het „verspringen" der vlekhelften ten opzichte van elkaar bij dezelfde veer blijkt het, dat ieder der vlaghelften een zekere zelfstandigheid heeft behouden.

$4^{0}$. Uit het voorkomen van slechts zeer weinige veeren, welke het "verspringen" dezer vlekhelften vertoonen, volgt, dat de beide vlaghelften in aanleg volkomen symmetrisch gebouwd zijn. Immers men vindt dit "verspringen" ook slechts bij veeren. welke niet geheel symmetrisch van bouw zijn. 
50. In het „verspringen" gedragen zich de vlekhelften volkomen als dwarsbanden.

60. Daar de parelvormige vlek stellig een niet primitieve figuur voorstelt, en deze vlek geheel eindstandig op de veer ligt, blijkt het, dat de veertop een niet primitief patroon kan dragen.

7. Daar de parelvormige vlek zeker een niet primitieve figuur voorstelt, blijkt het, dat de staartonderdekveeren bij dezen hoenderachtigen vogel nog een primitief karakter dragen. Immers deze veeren zijn de eenige veeren, welke de parelvormige vlek nog in den vorm van een witten dwarsband vertoonen.

$8^{\circ}$. Daar deze parelvormige vlek geheel eindstandig ligt (de schacht eindigt in haar midden), is deze vlek waarschijnlijk vergelijkbaar met den ocellus van Pavo.

$\mathbf{9}^{\circ}$. Daar bij dezen hoenderachtigen vogel de staartonderdekveeren wel primitief van karakter zijn, wat betreft de teekening, en de staartonderdekveeren bij Maleagris americana, zie $\mathrm{N}^{0}$. 7 , juist niet primitief van karakter zijn, blijkt het, dat een zelfde veerveld ten opzichte van de andere veervelden van denzelfden vogel een phylogenetisch ongelijkwaardig karakter kan dragen.

$10^{\circ}$. Hieruit volgt dus, dat Ermer's wet aangaande de postero-anteriore-ontwikkeling geen algemeene geldigheid heeft.

\section{$N^{0}$. 20. Tragopan temmincki $\sigma^{T}$.}

Vervolgt men tusschen nek en borst van het manlijke Temminck's Saterhoen de veeren rug-buikwaarts, dan treft men achtereenvolgens de volgende toestanden aan:

a. Eerste veer (Nekveer): Witte; eindstandige, ongepaarde parelvlek (zie №. 19). Iets lager vindt men op iedere vlaghelft een randstandige, (gepaarde), roode zijvlek (zie ook $\mathrm{N}^{0}$. 18).

b. Tweede veer: Als eerste, maar de roode zijvlekken en de parelvlek zijn meer over het verlengde van de veer uitgerekt, natuurlijk ten koste van de overige veerteekening.

c. Derde veer: Als tweede, maar de drie vlekken nog langer uitgerekt.

d. Vierde veer (Borstveer): De vlekken beslaan de geheele lengte van de veer en het geheel doet zich dus voor als een witte, overlangsche band op een rooden ondergrond.

Zie Pl. I. Fig. 4.

Conclusies:

$\mathbf{1}^{\mathbf{0}}$. Het blijkt, dat de witte, parelvormige vlek met een witten, overlangschen band samenhangt.

$2^{0}$. Daar deze witte, overlangsche band niet bij het wijfje voorkomt, noch bij den haan van Tragopan satyra of Tragopan melanocephalus, moet men deze teekening als een niet primitieve beschouwen.

$3^{0}$. Hieruit volgt, dat bij dezen haan het buikveld minder primitief is in een bepaald onderdeel der teekening (parelvormige vlek) dan de overige veervelden. Deze overlangsche banden komen n.l. uitsluitend op de buikveeren voor.

$4^{\circ}$. In verband met het voorgaande onder $\mathrm{N}^{0}$. 19 . blijkt het, dat een bepaalde vlek zoo* wel met dwarsbanden als met overlangsche banden kan samenhangen:

$5^{0}$. Indien de tweede conclusie juist is, volgt daaruit, dat de overlangsche streepteekening niet per se een phylogenetisch oude teekening is. Dit is in strijd met Emmis's wet.

Indien de tweede conclusie echter onjuist is, volgt uit deze vlektoestanden, dat het manlijke kleed (volgens EImer's wet) primitiever zou zijn dan het vrouwlijke bij dezen vogel. Dit laatste is zeer onwaarschijnlijk.

$6^{\circ}$. Het blijkt, dat men overlangsche strepen op veeren van verschillende vogelsoorten niet zonder nader onderzoek met elkaar mag vergelijken, daar zij op zeer verschillende wijzen kunnen ontstaan (zie Gennaeus lineatus $\mathrm{N}^{0} .14$ en Syrmaticus reevesi $\mathrm{N}^{0} .2 \%$ ). Het begrip overlangsche streep heeft slechts descriptieve waarde. 


\section{No. 21. Pavo cristatus $\sigma^{\top}$.}

Gelijk DaRwIN reeds aantoonde en ook door KERSchNer later uitvoeriger beschreven werd, vertoonen de zadelveeren van den Pauw (dus de zoogenaamde pauwenstaartveeren) alle graden van ontwikkeling tusschen de donsveer en de volmaakte oogveer. Men vindt al deze stadia van ontwikkeling met minutieus kleine verschillen op een zelfden volwassen vogel. KeRschnir beschouwde deze reeks van overgangen als een van phylogenetische waarde, ondanks dat $\mathrm{D}_{\text {ARwiN }}$ er op gewezen had, dat deze reeks volstrekt geen phylogenetische behoeft te zijn.

De pauwhaan verkrijgt in het begin van zijn 4 den jaar (dus drie jaar oud) het definitieve kleed. Dit kleed wijzigt zich elk jaar nog eenigszins, daar b.v. oudere pauwenhanen grootere ocelli bezitten dan jongere. Zoo kan men ook bij andere vogels leeftijdsverschillen in de veeren opmerken. Principieel blijft echter het kleed na het 3de jaar gelijk. Dit is niet het geval bij de $1^{\text {ste }}$ en $2^{\text {de }}$ jaars vogels. Deze dieren vertoonen telkens een ander beeld van. de zadelveeren. Ik moet hieraan toevoegen, dat de jonge vogels na het verlies der donsveeren, wat reeds enkele weken na de geboorte plaats vindt, dus in den middenzomer, een bepaald veerkleed krijgen, dat echter reeds weer in het najaar van hetzelfde geboorte-

jaar voor een gedeelte door rui vervangen wordt. Behalve het donskleed derhalve, dat ik niet nader beschrijven wil, vertoont de Pauwhaan gedurende de drie. eerste jaren van zijn leven vier verschillende veer-edities (zie definitie). Aldus:

Veereditie I (rui op den leeftijd van ongeveer 4 maanden):

a. Eerste veer: Top van zadelveer, welke halverwege op het zadel gelegen is. De veer vertoont onduidelijke, zigzagswijze verloopende, zwarte banden op bruingrijzen ondergrond. De meest eindstandige dezer banden is verbreed en treedt duidelijk op den voorgrond.

b. Tweede veer: Top van zadelveer, welke op $2 / 3$ van het zadel aan de staartzijde gelegen is. De veer vertoont in hoofdzaak hetzelfde beeld als de eerste veer.

c. Derde veer: Top van zadelveer, welke aan het eind van het zadel, dus tegen den staart aan, gelegen is.

De veer is in hoofdzaak als de eerste en tweede veer. Hier zijn echter alle zwarte dwarsbanden iets duidelijker ontwikkeld en de meest-eindstandige dwarsband treedt dus minder duidelijk op den voorgrond.

Zie Pl. II. Fig. 3.

Veereditie II (haan van ongeveer 1 -jaar):

a. Eerste veer: Afkomstig van lichaamsplaats als bij veereditie I.

De veer vertoont drie duidelijke, zwarte. dwarsbanden. De meest einstandige band is hier niet het duidelijkst ontwikkeld. Op alle drie de banden, vooral op de middelste, treden lichte dwarsbanden of dwarsstrepen op. Het zijn dus complexe banden.

b. Tweede veer: Afkomstig van lichaamsplaats als bij veereditie $I$. De veer vertoont eveneens de drie zwarte dwarsbanden. Hier ontbreken echter de lichte dwarsbanden.

c. Derde veer: Afkomstig van lichaamsplaats als bij veereditie I.

De veer vertoont meerdere zwarte dwarsbanden op lichten ondergrond. De drie bovenste banden dragen elk een lichten dwarsband. Deze drie banden zijn dus complex.

Zie Pl. II. Fig. 6.

Veereditie III (haan van ongeveer $1 \frac{1}{2}$ jaar):

a. Eerste veer: Afkomstig van lichaamsplaats als bij veereditie I.

De veer vertoont vijf donkere, grootendeels groen-glanzende dwarsbanden op lichten ondergrond. De tweede band is tegen het midden, dus tegen de schacht aan, naar boven en onderen ruitvormig verbreed. Op deze plaats is de groene glans het sterkste. De tweede en derde donkere dwarsband schijnen samen versmolten te zijn.

b. Tweede veer: Afkomstig van lichaamsplaats als bij veereditie I.

De veer vertoont aan den top onduidelijke resten van donkere dwarsbanden met 
groenen weerschijn, welke eindstandige banden onderling grootendeels versmolten zijn. Vooral tegen de schacht aan, waar een ruitvormige, bruine, met groenen weerschijn voorziene plek gelegen is, is deze versmelting zeer innig. Het overige gedeelte van de veer, het meer basaalwaarts gelegene, vertoont bruine, groenglanzende dwarsbanden op lichten ondergrond.

c. Derde veer: Afkomstig van lichaamsplaats als bij veereditie I.

Deze veer vertoont onduidelijke, vervormde, donkere dwarsbandeu, welke onregelmatig verloopen en een groenen weerschijn afwerpen.

Zie Pl. II. Fig. 10.

Veereditie IV (haan van ongeveer $2 \frac{1}{2}$ jaar):

a. Eerste veer: Afkomstig van lichaamsplaats als bij veereditie I.

Deze veer is geheel donker gepigmenteerd en draagt een groenen weerschijn. De overlangsche, uitgerekte, tegen de schacht aan gelegen, bruine plek vertoont in het midden een helderen, groenen weerschịn.

$b$. Tweede veer: Afkomstig van lichaamsplaats als bij veereditie I.

De veer is geheel donker gepigmenteerd en draagt een groenen weerschijn. Een bruine, waaiervormig-uitgebreide; eindstandige ringvlek vertoont een groenglanzend, eveneens ruitvormig centrum.

c. Derde veer: Afkomstig van lichaamsplaats als bij veereditie I.

De top dezer veer vertoont het typischen pauwenoog, dat geen nadere beschrijving behoeft. Vergelijk overigens No. 9.

Zie Pl. II. Fig. 9.

Men kan tusschen de hier telkens uitgekozen veeren ( $a$ eerste veer, $b$ tweede veer, $c$ derde veer) ondenkbaar vele overgangen bij een zelfden vogel, en dus behoorend tot hetzelfde zadel, vinden. Eveneens kan men tusschen een. donsveer en de eerste veer $(a)$ tallooze overgangsvormen op het lichaam opzoeken. Elke vogel draagt derhalve een volledige reeks veeren van donsveer tot de als derde veer $(c)$ beschreven veer. Dit geldt voor alle veeredities.

Conclusies:

$\mathbf{1}^{0}$. Het blijkt, dat een dwarsband-teekening optreedt bij de jongere veeredities van de pauw-zadelveeren, terwijl deze teekening bij de oudere veeredities totaal ontbreekt.

$2^{\circ}$. Het blijkt, dat complexe dwarsbanden ten nauwste verband houden met een ruitvormig-vervormde ringvlek.

$3^{\circ}$. Het blijkt, dat deze ruitvormig-vervormde ringvlek ten nauwste samenhangt met den ocellus.

$4^{0}$. Het blijkt, dat bij de wijziging van complexe dwarsband tot ocellus de teekening beperkt geworden is tot een tegen de schacht aan gelegen strook.

$5^{0}$. Het blijkt, dat de veerreeksen, welke men bij iedere veereditie vinden kan, principieel verschillend zijn, daar b.v. hier de vierde veereditie geen dwarsbandenstadium vertoont.

$6^{\circ}$. Het blijkt, dat de sterk op den voorgrond tredende, eindstandige, zwarte dwarsband van veereditie I bij veeredities van oudere vogels niet meer zoo duidelijk op den voorgrond treedt. Dit neemt niet weg, dat deze dwarsband reeds den veertop als een merkwaardige plaats kenmerkt. Later zal daar ter plaatse de ocellus optreden.

$7^{\circ}$. Indien men aanneemt, dat het jeugdkleed van een vogel een phylogenetisch ouder stadium vertoont dan het volwassenkleed, blijkt het, dat de reeks der zadelveeren (donsveer tot oogveer) van den volwassen Pauw geen zuiver-phylogenetische reeks is. Dit is dus in strijd met KeRSCHNER's opvatting.

Gebrek aan tijd noodzaakte mij de vier veeredities, die ik hier beschreef, van vier verschillende individuen te verzamelen. Voor de meeste ontogenetische onderzoekingen, ik geloof zelfs wel voor alle, is dit steeds de gebruikelijke methode van onderzoek, daar men nu eenmaal een dier of een lichaamsdeel noodzakelijker wijs slechts in dooden toestand ontleden kan. Dit is nu bij de veeren niet het geval en ik meen dus, dat het van belang is er op te wijzen, dat men hier een zeldzaam geval aantreft van materiaal, dat voor vergelijkend anatomisch onderzoek 
op ontogenetisch gebied geschikt is en dat men aan een zelfde dier meermalen en in verschillende ontwikkelingsstadiën ontleenen kan. Mij ontbrak echter de tijd hiertoe, daar ik dit te laat bedacht. Ik geloof overigens wel, dat het hoogst onwaarschijnlijk is, dat het zoo juist bedoelde onderzoek een ander resultaat zou hebben opgeleverd dan het boven medegedeelde.

\section{$N^{0}$. 22. Francolinus francolinus $\sigma^{7}$ en $ᄋ$.}

Bij den haan dezer soort treft men tegelijkertijd donker-zwarte borstveeren en witte buikveeren met zwarte dwarsbanden aan. De hen heeft eveneens witte buikveeren met zwarte dwarsbanden, maar deze dwarsbanden zijn nog veel smaller dan bij den haan. Vervolgt men borst-buikwaarts de veeren bij den haan dan vindt men er de volgende toestanden:

a. Eerste veer (Borstveer): De veer is geheel zwart.

b. Tweede veer: Als eerste, maar er bevindt zich één paar eindstandige, witte vlekken op den zwarten ondergrond.

c. Derde veer: Als tweede, maar er bevinden zich twee paar witte vlekken op den zwarten ondergrond. De beide eindstandige vlekken zijn volgens de richting van den veerrand uitgerekt.

d. Vierde veer: Als derde, maar er bevinden zich drie paar witte vlekken op den zwarten ondergrond. De eindstandige vlekken zijn in de richting van den veerrand, de anderen in overdwarse richting uitgerekt. De vlekken zijn gedeeltelijk onderling versmolten.

e. Vijfde veer: De veer als vierde, maar met vijf paar witte vlekken op den zwarten ondergrond. Deze vlekken zijn uitgerekt en ten deele versmolten. Zij vertoonen een dwarsbandachtig uiterlijk. .

$f$. Zesde veer: Als vijfde, doch de witte vlekken zijn nagenoeg tot witte dwarsbanden geworden, zoodat het zwarte pigment nu geheel op den achtergrond is gekomen. Bijgevolg is de hoofdmassa van de veer geheel wit.

g. Zevende veer (Buikveer): Deze veer vertoont drie zwarte dwarsbanden op witten ondergrond.

Aan deze zeven hanenveeren wil ik nog een hennenveer toevoegen, welke het verschijnsel van de buikveer $(g)$ nog duidelijker dan de hanenveeren vertoont:

h. Achtste veer (Buikveer, wijfje): Deze veer vertoont drie smalle, zwarte dwarsbanden op witten ondergrond.

Zie PI. I. Fig. 8.

Conclusies:

$1^{0}$. Het blijkt, dat er tusschen borst- en buikveer van dezen haan, ieder als vertegenwoordiger gekozen van een veerveld, min of meer geleidelijke overgangsvormen bestaan.

$2^{\circ}$. Het blijkt, dat het begrip ondergrond slechts descriptieve waarde heeft.

$3^{0}$. Het blijkt, dat het begrip teekening slechts descriptieve waarde heeft. Dit was nergens nog zoo opvallend als bij deze veeren.

$4^{0}$. Het blijkt, dat er samenhang bestaat tusschen vlekken en dwarsbanden.

$5^{0}$. De veer vertoont twee hoofdrichtingen van structuur:

a. Een dwarse structuur.

b. Een randstandige structuur.

\section{No. 23. Gennaeus swinhoei $ᄋ$.}

De vrouwlijke Swinhoe-fazant is voorzien van een zeer typische teekening op de meeste veeren van het lichaam. Deze teekening bestaat uit een lichtbruine, eindstandige, ongepaarde, ruitvormige vlek. Het overige veeroppervlak vertoont verder min of meer duidelijke, zigzagswijs verloopende, lichtbruine banden op zwarten ondergrond. Een reeks veeren genomen langs het midden van den rug van een zelfden vogel vertoont schouder-zadelwaarts de volgende patronen: 
a. Eerste veer (Schouderveer): Deze veer vertoont twee duidelijke, lichtbruine, naar boven scheef verloopende dwarsbanden.

b. Tweede veer: Als eerste, maar de scheefstelling der beide dwarsbanden is steiler, dus meer in overlangsche richting, terwijl de eindstandige, lichtbruine dwarsbanden het sterkst op den voorgrond treden.

c. Derde veer (Zadelveer): Deze veer is iets langer dan tweede, maar zij vertoont in hoofdzaak een zelfde beeld. Echter is de eindstandige, lichtbruine dwarsband geheel versmolten met zijn in spiegelbeeld gelegen evenbeeld op de andere vlaghelft. Deze beide dwarsbanden vormen dus tezamen een duidelijke, ruitachtige figuur, vooral ook, daar het zwarte pigment, dat de beide witte dwarsbanden bij de boven beschreven veeren omgeeft, hier ter plaatse sterk toegenomen is, waardoor de vlek nog duidelijker op den voorgrond treedt. Het meer naar den veerrand toe gelegen gedeelte der lichte dwarsbanden blijft ondanks de ruitvormige afsnoering nog aan den veerrand;

hoewel minder duidelijk, zichtbaar.

d. Vierde veer: Deze veer draagt een typische, ruitvormige vlek. Deze lichte vlek staat in geenerlei verband meer met de nog steeds zichtbare, hoewel veel minder duidelijke, zigzagswijze verloopende dwarbanden op het overige gedeelte van de veer.

Zie Pl. IV. Fig. \%.

Conclusies :

$1^{0}$. Het blijkt, dat de typische, ruitvormige, eindstandige, lichtbruine vlek met den scheef gestelden dwarsband samenhangt.

$2^{\circ}$. Het blijkt; dat twee op het eerste gezicht zeer verschillende patronen, zeer goed van elkaar kunnen afgeleid worden.

$3^{0}$. Daar scheefgestelde dwarsbanden bij vogelveeren zeer vaak voorkomen, is derhalve de ruitvormige figuur waarschijnlijk een phylogenetisch jonge veeruiting.

\section{No. 24. Thaumalea amherstiae $\sigma^{T}$.}

Vervolgt men rug-borstwaarts bij den Amherstfazant-haan de veeren, dan vindt. men tusschen de groenglanzende rugveeren en de witte borstveeren ter linker zijde van den vogel de volgende overgangsstadia. Aldus:

$a$. Eerste veer (Rugveer): Beide vlaghelften van de veer glanzend groen, met niet-glanzenden, zwarten, eindstandigen, randstandigen band.

b. Tweede veer: Als eerste, maar op rechter vlaghelft boven den zwarten band een verlengde, eindstandige, witte top.

c. Derde veer: Als tweede, maar de witte top is veel breeder en grijpt ook over de linker vlaghelft heen. Op den witten top ziet men nog weder een scheiding volgens een randstandige lijn. Op de rechter vlaghelft is in het basale gedeelte van het zwartgroen een witte vlek zichtbaar.

d. Vierde veer: Als derde, maar nu is de geheele veertop wit. De randstandige lijn in het wit is duidelijk zichtbaar.

e. Vijfde veer: De rechter vlaghelft dezer veer is op een klein, zwart basaalstuk na geheel wit. Ter linker zijde is nog glanzend groen aanwezig. In het ter linker zijde gelegen, basale, donkere groen is een witte vlek zichtbaar juist op dezelfde hoogte, waarop de grens wit-zwart bij de rechter vlaghelft gelegen is.

$f$. Zesde veer (Borstveer): Deze veer is geheel wit met uitzondering van een klein, zwart basaalstuk. Bij deze witte borstveer is nog steeds een randstandige lijn in het wit zichtbaar.

Zie Pl. III. Fig. 12.

Conclusies:

$1^{0}$. Het blijkt, dat er tusschen rug- en buikveer, ieder als vertegenwoordiger gekozen van een veerveld, min of meer geleidelijke overgangśvormen bestaan. 
$2^{\circ}$. Het blijkt, dat de scheiding tusschen twee veerpatronen onafhankelijk is van de individualiteit der veeren. Deze scheiding kan derhalve midden door een veer heen verloopen.

$3^{\circ}$. Hieruit volgt weder, dat deze op een scheiding gelegen veeren geen typisch eigen patroon dragen, maar het patroon van het veerveld of van de veervelden vertoonen, waartoe zij overeenkomstig haar plaatsing op het lichaam mede deel uitmaken.

$4^{0}$. Het blijkt, dat een zelfde veerpapil ondanks het feit, dat rug- en borstveer geheel verschillend zijn, tegelijkertijd het eene als het andere patroon kan voortbrengen.

$5^{0}$. Het blijkt, dat vormverandering bij de veer kan samengaan met kleurverandering.

$6^{0}$. Het blijkt, dat de veerschacht een zeer merkwaardige lijn is, wat betreft de veerkleur en de veerteekening, daar deze beiden bij voorkeur volgens de schachtlijn een scherpe grens blijken te vertoonen.

ro. Het blijkt, dat een vlek een aanduiding kan zijn van een dwarslijn, welke bij andere veeren twee kleuren van elkaar scheidt.

$8^{\circ}$. Het blijkt, dat het patroon der eerste veer $(a)$ slechts ten deele vergelijkbaar is met het patroon der derde veer $(c)$, daar deze laatste veer als het ware een witte, eindstandige randstrook langer is.

$9^{\circ}$. Hieruit volgt, dat men gerechtigd is, bij vergelijk van twee patronen van veeren toebehoorende aan twee verschillende vogels, slechts een gedeelte van het patroon der eerste veer te vergelijken met het geheele patroon der andere veer (vergelijk $P h a-$ sianus en Syrmaticus $\mathrm{N}^{0} .26$ en $\mathrm{N}^{0} .2 \%$ ).

\section{No. 25. Phasianus $\sigma^{\top} \sigma^{\top}$ en Syrmaticus $\sigma^{\top}$.}

De middelste staartpennen der hanen dezer geslachten vertoonen dwarsbanden op anderskleurigen ondergrond. Bij eenige soorten, welke ik als voorbeeld gekozen heb, is de teekening aldus :

a. Phasianus mongolicus:

De staartveer vertoont donkere strepen op bruinen ondergrond. Deze strepen zijn ter weerszijde door een lichtere zone vergezeld. Langs den veerrand vertoont de ondergrond een overlangsche strook met paarsen weerschijn. Daar ter plaatse zijn de dwarsstrepen verbreed tot dwarsbanden en veel onduidelijker afgeteekend.

b. Phasianus versicolor:

De staartveer vertoont een overlangsche reeks van gepaarde, tegen de schacht aan gelegen, min of meer afgeronde, zwarte plekken op een grijsbruinen ondergrond. Elk dezer vlekken is door een lichte zone omgeven. De grijsbruine ondergrond verloopt als een rechte, overlangsche band ter weerszijde van de veerschacht, terwijl de overblijvende veer-randstrooken bruin-paars zijn. Op dit bruin-paarse gedeelte van de veer is geen spoor van dwarsbanden meer te zien.

c. Syrmaticus reevesi:

De staartveer vertoont zwarte dwarsbanden op witten ondergrond. Deze witte ondergrond verloopt als rechte, overlangsche band ter weerszijde van de schacht. De overblijvende veerranden zijn okergeel. Op deze okergele, randstandige banden is geen spoor van zwarte dwarsbanden te zien.

Ik moet hieraan toevoegen, dat de onderkant van deze staartveer geheel zwart ziet.

Zie Pl. I. Fig. 12.

Conclusies:

$1^{\circ}$. De hier beschreven drie patronen gelijken zoo zeer op elkaar, dat men er uit besluiten mag, dat zij even vele varianten van een zelfde hoofdpatroon of oerpatroon voorstellen.

$2^{0}$. Het blijkt, dat er verband bestaat tusschen gepaarde ringvlekken en dwarsbanden.

$3^{0}$. Het blijkt, dat van deze drie vogelsoorten Phasianus mongolicus het eenvoudigste patroon draagt, daar bij deze soort de dwarsbanden tot den veerrand toe doorloopen. Deze conclusie geldt natuurlijk uitsluitend voor de staartveeren. 
$4^{0}$. Bij de wijziging van dwarsband tot ringvlek (Phasianus versicolor) is de teekening beperkt geworden tot een tegen de schacht aan gelegen strook (vergelijk ook $\mathrm{N}^{0} \mathrm{~s} .9$ en 12).

$5^{0}$. De veeren vertoonen twee hoofdrichtingen van structuur.

a. De dwarse structuur.

b. De overlangsche structuur.

$6^{0}$. Het blijkt, dat men patronen van verschillende kleur met elkaar vergelijken mag (zie ook $\mathrm{N}^{0}$. 17 en $\mathrm{N}^{0}$. 26).

$N^{0}$. 26. Phasianus $\sigma^{\nearrow}$ en . . (Vergelijk ook $N^{0} .27$ en $\left.N^{0} .32\right)$.

I. Schouderveer.

De schouderveeren der Phasianus-hanen vertoonen een zeer typische teekening, welke in min of meer gewijzigden vorm optreedt. Op het eerste gezicht is deze teekening bij de hanen geheel anders als bij de hennen. Toch zijn beide teekeningen ten nauwste aan elkaar verwant. Dit blijkt uit de volgende voorbeelden:
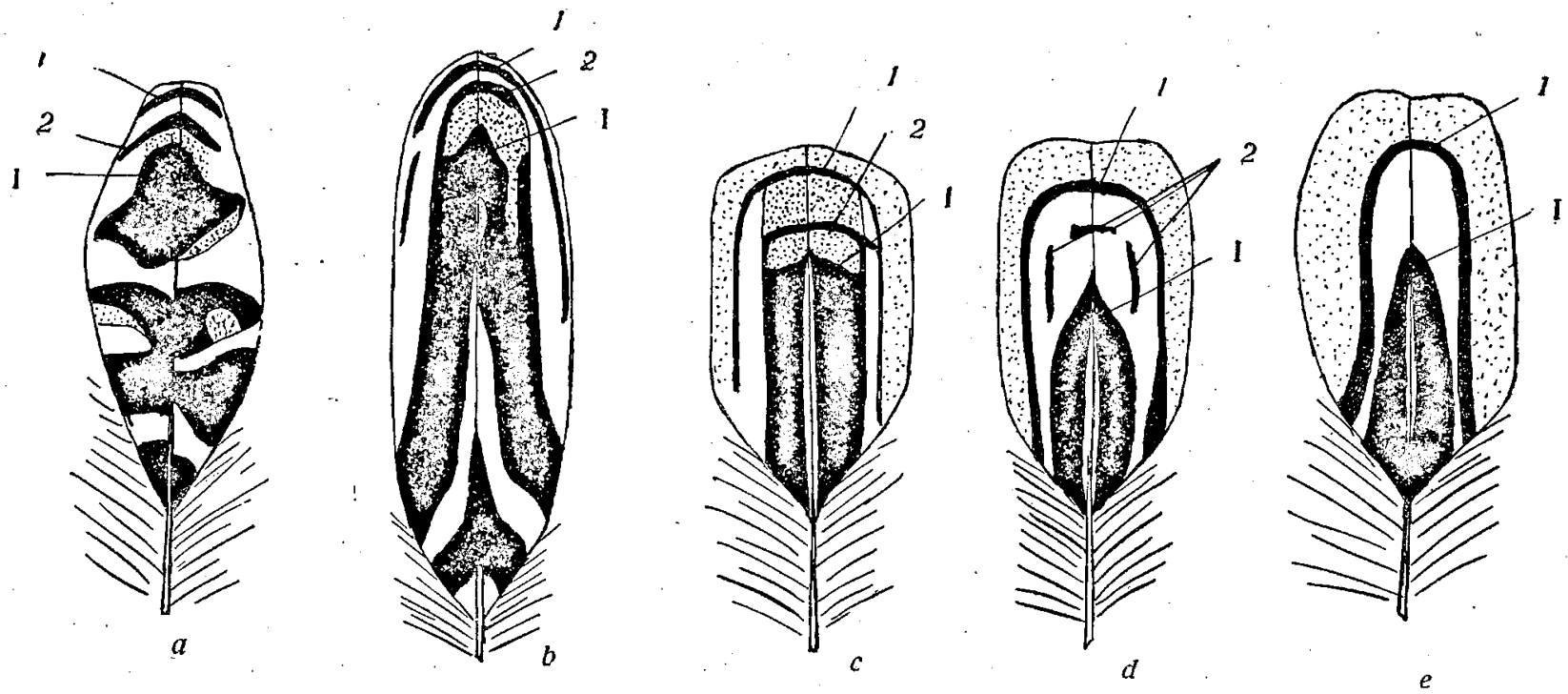

Fig. 3. Schouderveeren van Phasianus mongolicus $ᄋ$ en Phasianus satcheunensis $q$ 우 en $0^{7} \sigma^{7}$. De cijfers duiden correspondeerende elementen der teekening aan. (Vergelijk Plaat IV fig. 1.)

a. Phasianus mongolicus $ᄋ$ :

De veer vertoont breede, naar de schacht toe verdikte en als het ware gecontraheerde, onregelmatige, soms bovendien onderling versmolten, zwarte dwarsbanden. De twee bovenste, meest eindstandige banden zijn niet veel meer dan dwarsstrepen ( 1 en 2).

b. Ph. satcheunensis $\mathrm{Q}$ :

Veer als $a$, maar in overlangsche richting zijn de dwarsbanden versmolten tot twee scheefgestelde, breede dwarsbanden, welke zeer steil naar boven verloopen. De eerste dezer beide banden (I) is op de rechter vlagheltt nog onregelmatig, daar de samenstellende onderdeelen niet geheelenal versmolten zijn. De eerste, uiterste, zwarte dwarsstreep (1) is tot een randstandige streep geworden, vermoedelijk eveneens door versmelting met de uiteinden van de tweede, lager gelegen streep (2). Deze laatste is eveneens een randstandige geworden. Deze streep vormt dus als het ware een kap op het zwarte massief der versmolten dwarsbanden. De inhoud dezer kap is donkerder bruin dan de ondergrond.

c. Ph. satcheunensis $\&$ (arrhenoidie):

De veer als $b$, maar de zwarte, scheefgestelde banden (I) verloopen nu overlangs, terwijl zij een lichte schachtstreep overlaten. Buiten de eerste, uiterste randstreep (1) 
vindt men op de beide vlaghelften een randstandigen, bruinen band. De eerste, uiterste, randstandige streep (1) is nu zoo lang geworden, dat zij met het zwarten massief der versmolten dwarsbanden (I) evenwijdig loopt, terwijl er tusschen beiden in een overlangsche streep ter weerszijde overblijft.

d. Ph. satcheunensis . $0^{7}$ (1 jaar oud):

De veer als $c$, maar als het ware zuiverder afgewerkt. De eerste, randstandige streep (1) is nu geheel door een bruinen, randstandigen band omgeven. De tweede, randstandige streep (2) is nog als drie laatste resten herkenbaar op den nu gevormden spiegel. Het zwarte massief (I) is toegespitst, de schachtstreep is wit.

e. Ph. satcheunensis ơ (volwassen, ouder dan 3 jaar):

Veer als $d$, maar tweede, randstandige streep (2) geheel verdwenen, waardoor de spiegel zich $\mathrm{nu}$ geheel vlekkeloos voordoet. De buitenste, bruine, randstandige band is nog breeder dan bij $d$. Het zwarte massief $(\mathrm{I})$ is in vlekjes opgelost, de schachtstreep is wit.

Zie PI. IV. Fig. 1 en tekstfig. 3.

Conclusies:

$\mathbf{1}^{0}$. Het blijkt, dat bij deze ingewikkelde patronen het manlijke en het vrouwlijke patroon toch ten nauwste samenhangen.

$2^{\circ}$. Het blijkt, dat scheefgestelde dwarsbanden ontstaan kunnen door overlangsche versmelting van echte dwarsbanden. In dit geval zijn zij dus niet identiek gelijk met dwarsbanden.

$3^{0}$. Het blijkt, dat hier het vergelijkbaar manlijk patroon een kleiner gedeelte van de veer beslaat dan het vergelijkbaar vrouwlijk patroon.

$4^{0}$. Het blijkt, dat het arrhenoide vrouwlijk patroon niet identiek gelijk is aan het manlijk patroon, maar een overgangsstadium vertoont tusschen het echte manlijke en het echte vrouwlijke patroon.

$5^{0}$. Het blijkt, dat het jeugd-manlijk patroon niet identiek gelijk is aan het manlijk patroon, maar een overgangsstadium vertoont tusschen het echte manlijke en echte vrouwlijke patroon.

$6^{\circ}$. Het blijkt uit de eerste veer $(a)$, dat bij de wijziging van het dwarsbandenpatroon de teekening neiging heeft zich te beperken tot een tegen de schacht aan gelegen strook. (Vergelijk $\mathrm{N}^{0}$ s. 9, 12 en 26).

II. Vleugel-dekveer.

De vleugel-dekveeren der Phasianus-hanen vertoonen eveneens een typische teekening. De voorbeelden zijn aldus gekozen:

a. Phasianus satcheunensis ?:

De veer vertoont dwarsbanden op lichteren ondergrond. Het schachtstandige deel der banden bestaat uit een geconcentreerde vlek van zwart pigment; het randstandige deel is lichter bruin. De dwarsbanden raken den veerrand niet geheel.

b. Ph. satcheunensis o (arrhenoidie):

Een ietwat scheef op het lichaam ingeplante, dus asymmetrische veer, vertoont links in overlangsche richting een duidelijke versmelting van het zwarte pigment der dwarsbanden. Op de rechter vlaghelft is de versmelting nog inniger. Langs den rand vindt men een bruine, overlangsche, randstandige strook. De veer vertoont dus als het ware ter linker zijde een phylogenetisch jonger stadium dan ter rechter zijde.

c. Ph. satcheunensis ơ (volwassen, ouder dan 3 jaar):

De veer als $b$, maar het zwarte pigment is hier blauwgrijs gekleurd. Er zijn hier twee scheefgestelde, blauwgrijze dwarsbanden ontstaan. Langs den veerrand vindt men op iedere vlaghelft een bruine, overlangsche randstrook.

Zie Pl. IV. Fig. 5.

Conclusies:

$1^{\circ}$. Het blijkt, dat bij deze ingewikkelde patronen het manlijk en het vrouwlijk patroon toch ten nauwste samenhangen. 
$2^{\circ}$. Het blijkt, ' dat scheefgestelde dwarsbanden ontstaan kunnen door overlangsche versmelting van echte dwarsbanden. In dit geval zijn zij dus niet identiek gelijk met dwarsbanden.

$3^{0}$. Het blijkt, dat hier het vergelijkbaar manlijk patroon een kleiner gedeelte van de veer beslaat dan het vergelijkbaar vrouwlijk patroon.

$4^{0}$. Het blijkt, dat het arrhenoide vrouwlijk patroon niet identiek gelijk is aan het manlijk patroon, maar een overgangsstadium vertoont tusschen het echte manlijke en het echte vrouwlijke patroon.

$5^{0}$. Het blijkt uit de eerste veer $(a)$, dat bij de wijziging van het dwarsbandenpatroon de teekening neiging heeft zich te beperken tot een tegen de schacht aan gelegen strook. (Vergelijk $\mathrm{N}^{0} \mathrm{~s} .9,12,26$ ).

$6^{\circ}$. Het blijkt, dat men patronen van verschillende kleur met elkaar vergelijken mag (zie ook $\mathrm{N}^{0} .17$ en $\mathrm{N}^{0}$. 25). Immers de blauwgrijze teekening van den haan mag men zonder twijfel vergelijken met de zwarte teekening van de hen.

III. Zadelveer.

De zadelveer der Phasianus-hanen vertoonen eveneens een typische teekening. De voorbeelden zijn aldus gekozen:

a. Ph. satcheunensis :

De veer vertoont dwarsbanden op lichteren ondergrond. Het schachtstandige deel der banden bestaat uit een geconcentreerde, zwarte pigmentvlek; het randstandige gedeelte is lichter bruin. Aan den top der veer vindt men een zeer flauwe aanduiding van een eindstandige, randstandige streep.

b. Ph. satcheunensis :

De veer, welke uit hetzelfde zadel genomen is als $a$, dus van denzelfden vogel, vertoont een overlangsche versmelting van de geconcentreerde, zwarte, schachtstandige vlekken. Verder als $a$.

c. Ph. satcheunensis $\&$ (arrhenoidie):

Het patroondragende gedeelte van de veer is aanmerkelijk korter geworden dan bij $a$ en $b$, wat samengaat met een vergrooting van het donsachtige gedeelte der veer. Evenwel is de veer in haar geheel kleiner dan veer $a$ en $b$. Veerteekening als bij $b$, maar de randstandige streep is duidelijker en verloopt nu op verderen afstand van den veerrand. Ook is de versmelting der zwarte vlekken onderling inniger.

d. Ph. satcheunensis ơ (1 jaar oud):

De veer is als $c$, maar de randstandige streep is nu zeer duidelijk, terwijl de uiterste veerrand hier grijsgroen van kleur is geworden. Van den uitersten, zwarten dwarsband der wijfjes vindt men nog slechts resten terug, welke op den nu gevormden spiegel liggen.

e. Ph. satcheunensis on (volwassen, ouderdom, 3 jaar):

Veer als $d$, maar hier is de uiterste veerrand niet grijsgroen doch bruin van kleur. De randstandige streep is zwaar, zoodat men haar randstandigen band kan heeten. Men treft hier twee scheefgestelde dwarsbanden aan, waarvan de bovenste de plaats van den spiegel. voor een gedeelte beslaat. Het was mij onmogelijk om uit te maken of de bij $d$ reeds genoemde, rudimentaire, bovenste dwarsband aan dezen scheefgestelden dwarsband pigment heeft afgestaan.

Zie Pl. IV. Fig. 3.

Conclusies:

$1^{0}$. Het blijkt, dat bij deze ingewikkelde patronen het manlijke en het vrouwlijke patroon toch ten nauwste samenhangen.

$2^{\circ}$. Het blijkt, dat scheefgestelde dwarsbanden ontstaan kunnen door overlangsche versmelting van echte dwarsbanden. In dit geval zijn zij dus niet identiek gelijk met dwarsbanden.

$3^{0}$. Het blijkt, dat hier het vergelijkbaar manlijk patroon een kleiner gedeelte van de veer beslaat dan het vergelijkbaar vrouwlijk patroon. 
40. Het blijkt, dat het arrhenoide, vrouwlijk patroon niet identiek gelijk is aan het manlijk patroon, maar een overgangsstadium vertoont tusschen het echte manlijke en het echte vrouwlijke patroon.

$5^{0}$. Het blijkt, dat het jeugd-manlijk patroon niet identiek gelijk is aan het manlijk patroon, maar een overgangsstadium vertoont tusschen het echte manlijke en het echte vrouwlijke patroon.

$6^{\circ}$. Het blijkt uit de eerste veer $(a)$, dat bij de wijziging van het dwarsbandenpatroon de teekening neiging heeft zich te beperken tot een tegen de schacht aan gelegen strook (vergelijk $\mathrm{N}^{0}$ s. 9,12 en 26).

70. Het blijkt, dat men patronen van verschillende kleur met elkaar vergelijken mag (zie ook $\mathrm{N}^{0} \mathrm{~s}, 17$ en 25). Immers het randstandige grijsgroen van den eenjarigen haan is rechtstreeks vergelijkbaar met het randstandige bruin van den volwassen haan.

80. Het blijkt uit I, II en III, dat de vrouwlijke veeren het meest aan elkaar gelijk en dus waarschijnlijk het primitiefst zijn.

$9^{\circ}$. Hieruit volgt, dat het dwarsbanden-patroon jrimitief is. (Zie Ermer).

$10^{\circ}$. Het blijkt, dat de omvorming van een dwarsbandendragende, manlijke of vrouwlijke veer tot de het typisch manlijke veerpatroon dragende veer, hoe verschillend dit manlijke patroon ook zijn moge, geleidelijk plaats vindt en wel steeds in denzelfden zin n.l., dat de wijziging bestaat in een samenstelling van het dwarsbandenmateriaal van meer dan een dwarsband tot een gewijzigde, typisch manlijke figuur.

11. Pro memorie: zie Syrmaticus reevesi $\sigma^{7}$ en o $\mathrm{N}^{0} .2 \%$.

\section{$N^{0}$. 27. Syrmaticus reevesi $\sigma^{7}$ en}

De veeren dezer fazantensoort zijn mij eerst begrijpelijk geworden, wat hun veerpatroon betreft, na een vergelijk met de Phasianus-soorten. Jonge dieren dezer soort stonden mij helaas niet ten dienste, en het vrouwlijk dier vertoont reeds een niet-primitief, immers zeer gewijzigd, eigen patroon, dat op het eerste gezicht geheel verschillend is van het patroon van den haan. Beschrijft men de veeren in dezelfde volgorde, als bij Phasianus (zie $\mathrm{N}^{\circ} .26$ ) geschiedde, dan luidt de beschrijving aldus:

I. Schouderveer.

De schouderveer van den haan (b) vertoont een zwarten, randstandigen band, welke een spiegel insluit, en twee zwarte, eenigszins onregelmatige, scheefgestelde dwarsbanden op lichten ondergromd. De spiegel is gelegen tusschen den randstandigen band en den eersten dwarsband. Deze veer is zeer goed vergelijkbaar met de schouderveer van Phasianus $\sigma^{7}\left(\mathrm{~N}^{0} .26\right.$ I. e), wanneer men zich den bruinen, randstandigen band van Ph. satcheunensis $\sigma^{7}$ wegdenkt. (Vergelijk de arabische en romeinsche

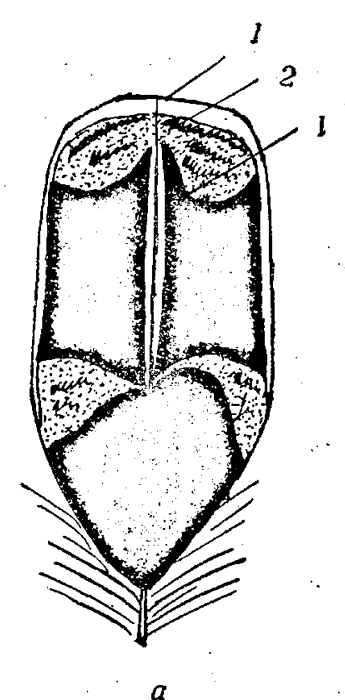

Fig. 4. Schouderveeren van Syrmaticus reevesi $\rho_{\text {en }} \sigma^{7}$. Vergelijk Plaat IV. Fig. 2. cijfers der tekstfiguren 3. en 4. en Pl. IV. Fig. 1 en 2).

De schouderveer van de hen $(a)$ vertoont een witte schachtstreep en een breeden, zwarten, van boven uitgeholden dwarsband, welke niet geheel tot den veerrand reikt. Langs den veerrand toch bevindt zich een witte, overlangsche streep. Het overige gedeelte van de veer is bruin en vertoont zigzagswijs verloopende, overdwarse strepen, waarvan sommige onderling versmolten zijn. Deze veer is zeer goed vergelijkbaar met de schouderveer van $P h a-$ sianus $\left(\mathrm{N}^{0} .26 \mathrm{I}\right.$. $\left.c\right)$, wanneer men zich den bruinen, randstandigen band wegdenkt. De zwakke, 
randstandige streep ontbreekt dan eveneens. (Vergelijk de arabische en romeinsche cijfers der tekstfiguren 3. en 4. en Pl. IV. Fig. 1 en 2).

Zie Pl. IV. Fig. 2. en tekstfig. 4.

Conclusies:

$1^{0}$. Het blijkt door vergelijking met het in de conclusies van $N^{0} .26$ gevondene, dat $P h a$ sianus en Syrmaticus een zeer verwant patroon vertoonen.

$2^{0}$. Het blijkt, dat een op zich zelf niet meer primitief gekleurde hen hier normaliter een veerpatroon vertoont, dat rechtstreeks vergelijkbaar is met het arrhenoide veerpatroon van de Phasianus-hen.

$3^{0}$. Het blijkt, dat het patroon eener veer in zijn geheel vergelijkbaar kan ziju met een deel van het patroon eener veer bij een andere species.

40. Pro memorie: conclusies als de eerste zes bij Phasianus $\mathrm{N}^{0}$. 26 .

II. Vleugel-dekveer.

De vleugel-dekveer van den haan $(b)$ vertoont een breeden, zwarten, randstandigen band en een overlangschen, van onderen iets naar buiten wijkenden band langs de witte schacht. Deze veer is zeer goed vergelijkbaar met de vleugel-dekveer van Phasianus $\sigma^{7}\left(\mathrm{~N}^{0} .26\right.$ II. c), wanneer men zich den bruinen, randstandigen band van $P h$. satcheunensis ơ wegdenkt.

De vleugel-dekveer van de hen $(a)$ vertoont resten van vijf overlangs versmolten, zwarte dwarsbanden. De witte schachtstreep is klaarblijkelijk eveneens door overlangsche versmelting ontstaan. De twee bovenste, zwarte dwarsbanden zijn het duidelijkst. Zij raken den veerrand niet. De veerranden zijn in overlangsche richting lichtbruin. Deze veer is zeer goed vergelijkbaar met de vleugel-dekveer van Phasianus $\&$ ( ${ }^{0} .26$ II. b), wanneer men zich den bruinen, randstandigen band van $P h$. satcheunensis o wegdenkt.

Zie Pl. IV. Fig. 8.

Conclusies:

$1^{0}$. Het blijkt door vergelijking met het in de conclusies van $\mathrm{N}^{0} .26$ gevondene, dat $P h a-$ sianus en Syrmaticus een zeer verwant patroon vertoonen.

$2^{0}$. Het blijkt, dat een op zich zelf niet meer primitief gekleurde hen hier normaliter een veerpatroon vertoont, dat rechtstreeks vergelijkbaar is met het arrhenoide veerpatroon van de Phasianus-hen.

$3^{0}$. Het blijkt, dat de lichte, overlangsche schachtstreep uit overlangsche versmelting van lichte dwarsbanden ontstaan is.

$4^{0}$. Het blijkt, dat het patroon eener veer in zijn geheel vergelijkbaar kan zijn met een deel van het patroon eener veer bij een andere species.

III. Zadelveer.

De zadelveer van den haan $(b)$ vertoont een randstandigen band en een zwarten schachtband op gelen ondergrond. $\mathrm{Na}$ al het bovengezegde mag men deze veer wel vergelijken met de zadelveeren van Phasianus $\sigma^{\top}\left(\mathrm{N}^{0} .26\right.$ III. $d$ en $e$ ).

De zadelveer van de hen $(\alpha)$ vertoont een langen, met scheefverloopende zijden voorzienen, overlangschen band op donkeren ondergrond. Deze band draagt weer zigzagswijs verloopende dwarsstrepen. De veer is na het bovengezegde zeer goed vergelijkbaar met de zadelveer van Phasianus ᄒ (Nº. 26 III. c).

Zie Pl. IV. Fig. 4.

Conclusies:

$1^{0}$. Het blijkt door vergelijking met het in de conclusies van $\mathrm{N}^{0} .26$ gevondene, dat Phasianus en Syrmaticus een zeer verwant patroon vertoonen.

$2^{0}$. Het blijkt, dat een op zich zelf niet meer primitief gekleurde hen hier normaliter een veerpatroon vertoont, dat rechtstreeks vergelijkbaar is met het arrhenoide veerpatroon van de Phasianus-hen.

3. Het blijkt, dat de veerpatronen van twee genera duidelijke verwantschap vertoonen.

$4^{0}$. Het blijkt, dat het patroon eener veer in zijn geheel vergelijkbaar kan zijn met een deel van het patroon eener veer bij een andere species. 


\section{$N^{0}$. 28. Thaumalea hybrida $\delta^{\top}$ (T. picta $\sigma^{\top} \times$ T. amherstiae $^{\prime}$ ).}

De veeren van dezen door mijzelf gekweekten bastaard-haan vertoonen 0 . $\mathrm{m}$. een merkwaardige reeks van overgangsvormen, wanneer men de veeren nek-borstwaarts vervolgt. Men treft dan achtereenvolgens de volgende overgangstoestanden aan op de linker flank van het dier:

a. Eerste veer (Rugveer): De beide vlaghelften dezer veer zijn glanzend groen met een niet groenglanzenden, bijna eindstandigen, zwarten, randstandigen band. Aan het basale gedeelte der veer, even boven het donzige voetstuk, ziet men een lichtbruinen, scheefgestelden dwarsband in het donkere, maar niet groenglanzende gedeelte der. veer.

b. Tweede veer: Als eerste, maar de randstandige band is breeder en op de rechter vlaghelft grootendeels rood gekleurd. De lichtbruine dwarsband is meer onregelmatig en verdubbeld.

c. Derde veer: Als tweede, maar het rood van den randstandigen band beslaat de geheele veerbreedte. Men ziet nog slechts op de linker vlaghelft een laatste rest van de proximaal gelegen, groenglanzende kleur, terwịjl het meest eindstandige gedeelte der veer op de rechter vlaghelft nu geel-wit gekleurd is. De veer is, blijkbaar in verband met deze geel-witte kleur ter rechter zijde, rechts langer dan links. De bovenste der beide onregelmatige, lichtbruine dwarsbanden is hier veel breeder vooral aan de rechter zijde, zoodat daar van de oorspronkelijke, groenglanzende kleur slechts weinig overblijft.

d. Vierde veer: Als derde, maar de eindstandige, geel-witte kleur is nog verder verbreid, zoodat zij nu ook de linker vlaghelft beslaat. In verband daarmede is het uiterste linker topgedeelte van deze veer korter dan de rest der veer. Ook ter linker zijde begint het oorspronkelijke, glanzende groen in omvang af te nemen, terwijl er ter rechter zijde nog slechts zeer weinig van over is. Intusschen is het basale gedeelte van de licht-bruine dwarsbanden, vooral ter rechter zijde, geel-wit van kleur geworden.

e. Vijfde, Deze veeren vertoonen de geleidelijke overgangen, die in het vol-

f. Zesde gende bestaan: De groenglanzende kleur gaat verloren evenals de

g. Zevende veer: roode kleur en de lichtbruine kleur, zoodat ten slotte de achtste veer

h. Achtste (h), op het basale gedeelte na, geel-wit is gekleurd. In het nog donkergekleurde, basale gedeelte der veer blijft de geelwitte, scheefgestelde dwarsband duidelijk zichtbaar.

i. Negende) Deze veeren vertoonen de geleidelijke overgangen, die in het vol-

$j$. Tiende veer. gende bestaan: Het proximale gedeelte der veer wordt steeds rooder,

$k$. Elfde veer: zoodat ten slotte de twaalfde veer $(l)$ aan den top geheel rood is en meer

$l$. Twaalfde basaalwaarts een geel-witte strook vertoont, terwijl het donkergekleurde, basale gedeelte der veer zich verkort voordoet en geen geel-witten, scheefgestelden dwarsband meer draagt.

Ik moet hier nog aan toevoegen, dat vanaf de vierde veer gerekend alle veeren, blijkbaar in verband met de geel-witte, eindstandige kleur, veel langer zijn dan de drie eerste veeren.

Zie Pl. III. Fig. 1.

Conclusies:

$1^{0}$. Het blijkt, dat er tusschen rug- en buikveer, ieder als vertegenwoordiger gekozen van een veerveld, min of meer geleidelijke overgangsvormen bestaan.

$2^{0}$. Het blijkt, dat de scheiding tusschen twee veerpatronen onafhankelijk is van de individualiteit der veeren. Deze scheiding kan midden door een veer heen verloopen.

$3^{0}$. Hieruit volgt derhalve, dat alle veeren, evenals deze scheidingsveeren, geen typisch eigen patroon dragen, maar het patroon van het veerveld of van de veervelden vertoonen, waarvan zij overeenkomstig hun plaatsing op het lichaam mede deeluitmaken. 
$4^{0}$. Het blijkt, dat eenzelfde veerpapil ondanks het feit, dat rug- en buikveer geheel verschillend zijn, tegelijkertijd zoowel het eene als het andere veerpatroon kan voortbrengen.

$5^{\circ}$. Het blijkt, dat bij dezelfde veer een vormverandering kan samengaan met een kleurverandering.

$6^{0}$. Het blijkt, dat de veerschacht een zeer merkwaardige lijn is, wat betreft de veerkleur en de veerteekening, daar deze beiden volgens de schachtlijn vaak een scherpe grens vertoonen.

\%o. Het blijkt, dat bij bastaarden een nieuw kleurveld kan optreden, hetwelk bij geen der beide ouders zichtbaar was: Thaumalea amherstiae heeft een groenen nek en een witte buik, Thaumalea picta heeft een groenen nek en een roode buik, Thaumalea hybrida heeft een groenen nek en een roode buik. Tusschen beiden in is bij T. hybrida een roomkleurig-wit veld gelegen. Dit roomkleurig-witte veld is bij verschillende bastaardhanen, van overigens gelijke afstamming, zeer ongelijk van afmeting.

\section{$N^{0}$. 29. Lophophorus impeyanus $\sigma^{7}$.}

De veeren van den Glansfazant-haan zijn over het algemeen geheel metaalglanzend. Hierop maken slechts de donsachtige voetstukken der veeren een uitzondering. Toch kan men bij meerdere veeren, o. a. bij de schouderveer, de oorspronkelijke dwarsbandenteekening zien, wanneer de richting van het invallende licht daartoe gunstig is.: De metaalglans, welke van recenten datum is, en het daarbij optredende, zwarte pigment heeft dus de oorspronkelijke dwarsbandenteekening nog niet geheel ovẹrdekt.

Zie Pl. I. Fig. 5.

Conclusie:

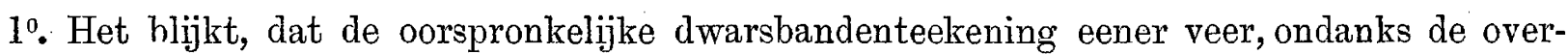
dekking door het later optredenden, zwarten pigment, als dusdanig nog in de metaalglanzende veer aanwezig kan zijn.

\section{$N^{\circ}$. 30. Gennaeus nycthemerus $\delta^{\top}$ :}

Een vleugelslagpen van den volwassen, manlijken Zilverfazant vertoont het rechtstreeksch verband tusschen dwarsbanden en randstandige banden. Men ziet op het basale veergedeelte scheef naar boven verloopende, zwarte dwarsbanden, waarvan de ondersten den veerrand raken, terwijl de hooger gelegen banden dit niet meer doen. De ondergrond is wit. Men ziet, dat deze dwarsbanden min of meer geleidelijk in randstandige banden overgaan. Ter rechter en linker zijde ziet men, dat op de overgangsplaatsen tusschen de randstandige en de scheefgestelde banden enkele duidelijke, vrij liggende, zwarte vlekken voorkomen. Deze vlekken bewijzen, dat de dwarsbanden niet zonder meer omgevormd zijn tot randstandige banden.

Zie Pl. III. Fig. 10.

Conclusies:

$1^{\circ}$. Het blijkt, dat er een nauw verband bestaat tusschen dwarsbanden en randstandige banden.

$2^{0}$. Het blijkt uit de losse, vrijliggende, zwarte vlekken, dat de randstandige banden en de dwarbanden niet identiek dezelfde banden zijn.

$3^{0}$. Hieruit volgt tevens, dat wel hetzelfde pigmentmateriaal voor beide soorten van banden gebruikt is.

\section{$N^{0}$. 31. Gennaeus nycthemerus $\sigma^{7}$.}

Een zadelveer van een volwassen, manlijken Zilverfazant vertoont randstandige strepen, welke de veerschacht tweemaal, zoowel proximaal als basaal, snijden. Vooral de beide middelste, randstandige strepen vertoonen dit verschijnsel zeer. duidelijk. De meer naar buiten gelegen strepen kunnen de schacht niet meer bereiken, daar hiertoe de veervlag te kort is. 
Denkt men zich echter beide strepen verlengd, dan zouden ook deze strepen de veerschacht tweemaal snijjden.

Zie Pl. III. Fig. 9.

Conclusies:

$1^{0}$. Het blijkt, daar zonder eenigen twijfel de hierboven genoemde, randstandige strepen dezelfde zijn als de de veerschacht slechts eenmaal snijdende strepen (welke op veeren voorkomen, die iets verder op het zadel gelegen zijn), dat er verband bestaat tusschen de schacht eenmaal en de schacht tweemaal snijdende, randstandige banden.

$2^{0}$. In verband met $N^{0} .30$ blijkt het, dat de de veerschacht tweemaal snijdende, randstandige banden en dwarsbanden aan elkaar verwant zijn. Hieruit volgt evenmin als bij. de de veerschacht eenmaal snijdende banden, dat deze beide soorten banden identiek dezelfde zouden zijn.

$3^{0}$. Uit $\mathrm{N}^{5}$ s. 30 en 31 volgt, dat de verschillende soorten van banden door vervorming (versmelting en oplossing) en niet door omvorming uit elkander ontstaan.

N0. 32. Phasianus colchicus $\sigma^{7}$ (Vergelijk ook №. 26).

Een jonge, eenjarige Boschfazant-haan, welken ik gedurende den eersten herfstrui onderzocht, droeg tegelijkertijd twee veeredities. Bij dezen vogel vooral was het interessant de patroonsverschillen der beide edities na te gaan. De vleugeldekveer (jeugd-editie $a$ en eerste hanen-editie $b$ ) zoowel als de zadelveer (jeugd-editie $c$ en eerste hanen-editie $d$ ), welke dus van een zelfde individu afkomstig zijn, vertoonen deze verschillen ten duidelijkste. Deze verschillen bestaan niet slechts in veerkleur- en veerteekeningverschillen, maar ook in veervormverschillen. Het blijkt, dat de jeugd-editie, wat veervorm betreft, een veel meer Gallusachtig voorkomen heeft. Voor de nadere patroonsbeschrijving vergelijke men $\mathrm{N}^{0} .26$.

Zie Pl. IV. Fig. 6.

Conclusie:

$1^{0}$. Het blijkt, dat een veer van de jeugd-editie somtijds een nadere verwantschap vertoont, wat den vorm betreft, met een veer van een ander genus dan de veeren van latere edities.

Aan de beschrijvingen, welke hier zijn voorafgegaan, en die allen van een of meer figuren vergezeld zijn, wil ik nog eenige beschrijvingen zonder eenige figuur of teekening toevoegen: Al deze hier volgende beschrijvingen zijn zoo eenvoudig .en de gevallen, welke zij behandelen, komen voor het meerendeel zoo algemeen voor, dat het mij toescheen, dat ik hier van afbeeldingen mocht afzien. Deze afzonderlijke beschrijvingen luiden:

\section{$N^{0}$. 33. Thaumalea picta $\sigma^{7}$.}

De onderarm-slagpennen van den volwassen Goudfazant-haan zijn egaal donkerbruin gekleurd. De buitenwaarts gelegen vlaghelft vertoont een randstandige, lichte streep. De slagpennen van een eenjarigen vogel verschillen hiervan in twee opzichten en wel: de veer is iets stomper, iets minder toegespitst, doch overigens gelijk in vorm. De teekening is echter geheel anders. Deze teekening bestaat bij den eenjarigen vogel uit duidelijke, lichte dwarsbanden op donkeren ondergrond. De dwarsbanden komen op beide vlaghelften voor, dus ook op de buitenwaarts gelegen vlaghelft.

Conclusies:

$1^{0}$. Het blijkt, dat veeren van verschillende veeredities niet gelijk in vorm zijn.

$2^{0}$. Het blijkt, dat asymmetrie in veervorm niet noodzakelijkerwijs gepaard gaat met asymmetrie in veerteekening.

$3^{0}$. Het blijkt, dat veervorm en veerteekening zich wel in dezelfde richting, maar toch onafhankelijk van elkaar kunnen ontwikkelen. In dit geval trad bij de veervorm het eerst wijziging op. 


\section{No. 34. Thaumalea amherstiae $\sigma^{7}$.}

De zadelveeren van den Amherstfazant-haan vertoonen een gouden topgedeelte en een groen voetgedeelte, waarop een of twee dwarsbanden verloopen. Vervolgt men de veeren rug-buikwaarts dan ziet men deze dwarsbanden geleidelijkaan verdwijnen en wel het eerst op de naar de buik toegekeerde vlaghelft.

Conclusie:

$1^{\circ}$. Het blijkt, dat de rugas voor de veeren, wat betreft de teekening, een as van symmetrie kan zijn.

\section{$N^{0}$. 35. Gallinae.}

Bij alle hoenderachtige vogels valt het op, dat de slagpennen, van den vleugel zoowel als van den staart, van de rugas af gerekend hoe langer hoe meer asymmetrisch worden, voor zoover het den vorm betreft. Dit geldt natuurlijk voor de linker zoowel als voor de rechter zijde van het dier, maar dan in tegengestelden zin.

Conclusie:

$1^{0}$. Het blijkt, dat de rugas voor de veeren, wat betreft den vorm, een as van symmetrie kan zijn.

\section{$N^{0}$. 36. Thaumalea $\sigma^{\top} \sigma^{T}$.}

De veeren van het voorste gedeelte van het zadel zijn bij de hanen van dit genus voorzien van een goudgelen top. Vervolgt men de veeren rug-buikwaarts dan verandert deze goudgele kleur geleidelijkaan en wel bij $T$. amherstiae in wit, bij de beide andere soorten van dit geslacht ( $T$. obscura en $T$. picta) in rood, dus bij alle drie de soorten in de kleur van het buikveld. Deze geleidelijkheid bestaat daarin, dat de naar de buikzijde toe gelegen vlaghelften het eerst en vervolgens het duidelijkst de kleur van de buik vertoonen.

Conclusies:

$1^{0}$. Het blijkt, dat de rugas voor de veeren, wat betreft de kleur, een as van symmetrie kan zijn.

$2^{0}$. Het blijkt, dat de grenslijn der veervelden van een zelfden vogel voor de veerkleur en den veervorm niet steeds dezelfde is. Immers de buik-ruggrens verloopt voor den veervorm meer buikwaarts dan voor de veerkleur.

\section{No. 37. Thaumalea picta .}

$O p$ het middengedeelte van den borst van de Goudfazant-hen vindt men lichtgrijze veeren zonder eenige bandteekening. Meer naar de flank toe treft men een duidelijker of minder duidelijke aanduiding van scheefgestelde dwarsbanden. Deze dwarsbandteekening is het sterkst ontwikkeld op de naar den rug toe gelegen vlaghelft. Op de flank van het dier wordt deze teekening hoe langer hoe meer volmaakt, naar mate men den rug meer nadert. Deze teekening verandert hoe langer hoe meer in een echte dwarsbandteekening.

Conclusies :

$1^{0}$. Het blijkt, dat de borstmiddellijn voor de veeren, wat betreft de kleur, een as van symmetrie kan zijn.

$2^{0}$. Het blijkt, dat de borstmiddellijn voor de veeren, wat betreft de teekening, een as van symmetrie kan zijn.

\section{$N^{0}$. 38. Thaumalea $\sigma^{7} \sigma^{7}$.}

Men vindt bij de hanen van dit genus op den rug een duidelijke indeeling in veervelden, welke zoowel den veervorm, de veerkleur als de veerteekening in gewijzigden vorm vertoonen. Hiervan is een indeeling het gevolg, welke een ieder dadelijk opvalt, en wel in:

Kuif, Kraag, Schouderdek, Zadel, enz. 
Bij nader onderzoek blijken tusschen deze veervelden allerlei geleidelijke overgangsveeren gelegen te zijn. Dit lijkt op het eerste gezicht zeer onwaarschijnlịjk, daar de velden den indruk maken van door scherpe grenzen te worden afgesloten. Deze verkeerde indruk komt daardoor tot stand, dat de grensstandige veeren van ieder veld veel korter zijn dan de meer middenstandige veeren. Deze meer middenstandige veeren overdekken derhalve de meer grensstandige veeren geheel en al. Hiervan is weer het gevolg, dat men met het bloote oog in hoofdzaak de middenstandige veeren der verschillende veervelden te zien krijgt. De middenstandige veeren der verschillende velden verschillen nu onderling in zoo groote mate, dat het op het eerste gezicht haast ondenkbaar lijkt, dat zij niets anders dan varianten van een zelfde thema voorstellen.

Conclusie:

$1^{0}$. Het blijkt, dat de op het oog door vorm, kleur en teekening zoo scherp gescheiden veervelden in werkelijkheid door vele overgangsveeren met elkaar verbonden zijn.

\section{$N^{0}$. 39. Syrmaticus reevesi $\delta^{7}$.}

De staartveer van den Koningsfazant-haan (zie ook $\mathrm{N}^{0}$. 25) is aan de bovenzijde zeer typisch met dwarsbanden en overlangsche banden geteekend, terwijl de onderzijde geheel zwart ziet. Een dergelijk verschijnsel vindt men meer bij fazanten, maar vooral ook bij papegaaien. Bij de meeste hoenderachtige vogels echter is de onderkant der veeren (de ventrale zijde) lichter gekleurd, terwijl de bovenkant (de dorsale zijde) een donkerder kleur of het patroon draagt. Het licht-van-kleur-zijn der ventrale zijde van de veer heeft ten gevolge, dat men over het algemeen den indruk krijgt, dat zoowel de ventrale als de dorsale zijde der veer dezelfde kleur of dezelfde teekening bezitten. Bij nadere beschouwing echter valt het dadelijk op, dat deze schijnbaar-ventrale kleur of dit schijnbaar-ventrale patroon veel minder duidelijk is dan het dorsale patroon en slechts doorschemert.

Bij de meeste veeren vertoont de achterschacht, welke steeds geheel donsachtig is, de bekende zilverachtig-grijze donskleur. Slechts als groote uitzondering vond ik bij achterschachten van dezen haan een flauwe dwarsbandteekening.

Conclusies:

$1^{0}$. Het blijkt, dat een veer een ventraal- en een dorsaalpatroon bezit.

$2{ }^{0}$. Het blijkt, dat bij hoenderachtige vogels slechts bij hooge uitzondering het ventrale veerpatroon donkerder van kleur is dan het dorsale veerpatroon.

$3^{\circ}$. Het blijkt, dat bij hoenderachtige vogels slechts bij hooge uitzondering de achterschacht en de achtervlag een dwarsbandenpatroon dragen.

\section{$\mathrm{N}^{0}$. 40. Pulli (Thaumalea amherstiae en Thaumalea picta).}

De kuikens dezer beide Thaumalea-soorten vertoonen een donkeren rug, waarop twee overlangsche, lichte strepen verloopen. Deze strepen strekken zich uit van af de schouderhoogte tot aan den staart. Zoodra zich echter de contourveeren beginnen te ontwikkelen, verdwijnen deze lichte strepen geheel en al. Daar de contourveeren gedurende den eersten tijd nog de kuikendonsveeren aan den top dragen, kan men duidelijk zien, wat er van deze lichte strepen geworden is. Bij een kuiken van $1 \frac{1}{2}$ maand is het mij bij onderzoek gebleken, dat de lichte rugstreepen niets anders zijn als de bij kuikens zichtbare aanduiding van de latere grenzen van het zadelveld.

Conclusies:

$1^{0}$. Het blijkt, dat de lichte, overlangsche kuikenstrepen, welke bestaan uit in hun geheel licht gekleurde veertjes, de grenzen van het latere zadel voorstellen.

$2^{0}$. Het blijkt derhalve, dat de overlangsche kuikenstrepen geheel iets anders zijn als de overlangsche veerstrepen of veerbanden van den volwassen vogel. 


\section{$\mathrm{N}^{0}$. 41. Lophophorus impeyanus ơ.}

De vleugelslagpennen van den Glansfazant-haan zijn donker gepigmenteerd en vertoonen een veelkleurigen glans. Bij een opgezet exemplaar trof ik, zoowel ter linker als ter rechter zijde, een enkele veer (in beide gevallen was het de vijfde bovenarmslagpen), welke niet donker gepigmenteerd en niet metaalglanzend is, en welke van een dwarsbandteekening, overeenkomend met die der jeugd-slagpennen dezer soort, voorzien is.

Conclusies:

$1^{0}$. Het blijkt, dat de niet-geleidelijkheid van overgang tusschen de slagpennen van dezen vogel moet verklaard worden door ongelijktijdigen rui.

$2^{\circ}$. Het blijkt derhalve, dat men bij vogels vaak een veerkleed aantreft, dat uit meer dan een veereditie tegelijk bestaat. (Dit was voor de vleugeI-slagpennen reeds bekend).

\section{$\mathrm{N}^{0}$. 42. Phasianus mongolicus}

Bij de'studie van een dertienjarige, arrhenoide hen dezer soort viel mij het groote verschil op, dat er bestaat tusschen de veeren van dit dier en de veeren eener arrhenoide hen derzelfde soort, welke eerst (hoogstens) tien jaar oud is. De tienjarige hen draagt arrhenoide veeren, welke een in teekening geheel henachtig, maar feller (dus haanachtig gekleurd) patroon dragen, terwijl de dertienjarige arrhenoide hen een in teekening veel meer haanachtig patroon, dat bovendien haanachtig gekleurd is, op haar veeren vertoont.

Conclusies:

$1^{\circ}$. Het blijkt; dat de arrhenoide veerpatronen bij dezelfde vogelsoort met den leeftijd der hennen mede een steeds meer manlijk karakter verkrijgen.

$2^{0}$. Het blijkt, dat bij deze fazanten-soort de arrhenoidie zich het eerst in de veerkleur uit, terwijl de veerteekening eerst veel later gewijzigd wordt.

$3^{0}$. Het blijkt, dat veerkleur en veerteekening zich wel in dezelfde richting, maar toch onafhankelijk van elkaar kunnen ontwikkelen. In dit geval trad bij de veerkleur het eerst wijziging op.

$N^{0}$. 43. Gennaeus swinhoei $\sigma^{x}$, Gennaeus nycthemerus $\sigma^{x}$, Gennaeus lineatus $\sigma^{x}$, Thaumalea picta $\sigma^{7}$, Thaumalea obscura $\sigma^{7}$ en Thaumalea amherstiae $\sigma^{7}$.

Op het geheele rug- en kopoppervlak van $T$. picta $\sigma^{\top}$ en $T$. obscura $\sigma^{\top}$ en op een groot gedeelte van het rug- en kopoppervlak van T. amherstiae $\sigma^{\top}, G$. swinhoei $\sigma^{\top}$, G. nycthemerus $\sigma^{\top}$ en $G$. lineatus $\sigma^{\pi}$ vertoonen de veeren een veel lichtere kleur dan op de buikzijde derzelfde vogels. Dit verschijnsel is voor vertebraten een exceptioneel verschijnsel, daar men het slechts bij enkele zoogdieren (o. a. bij den Das, zie WuBER „Biologie"), bij enkele vogels en bij enkele visschen aantreft. Dit verschijnsel is dan ook een uitzondering op den zeer algemeen geldenden regel, dat bij de Vertebraten de rugzijde van eenzelfde dier steeds donkerder van kleur is dan de buikzijde. Bij de hennen der hier genoemde soorten, evenals bij de jonge hanen en kuikens, treedt dit zoo merkwaardig uitzonderingsgeval niet op. Integendeel, daar is de uiting der veeren, wat betreft de kleur, een volkomen normale. Het blijkt nu, dat deze lichte rugzijde der manlijke, volwassen vogels ook eerst optreedt bij het op kleur komen der hanen en wel steeds in sterker mate, naarmate ook het dier nog in ouderdom toeneemt. Dit toenemen van de lichte kleur met den ouderdom beteekent daarom niet, dat men hier met een grijs-worden der veeren te doen heeft, gelijk men dit bij het haar der menschen kent. De witte of lichte kleur is bij deze fazanten geen ouderdomsverschijnsel in dien zin. Haar optreden is slechts een meer volmaakt-worden van een nieuw, waarschijnlijk recent patroon, dat zich geleidelijkaan, meestal vanuit eèn centrale, tegen de schacht aan gelegen plek als het ware meester maakt van het veeroppervlak. Van veereditie tot veereditie zien wij dit lichte patroon het oudere, (wat de kleur betreft) eenvoudigere patroon verdringen. De hier genoemde afwijking van het normale, algemeen geldende verschijnsel: „donkere rug en lichtere buik" is te merkwaardiger, daar het, gelijk ik zeide, niet voor de jonge dieren 
geldt. Wij zien hier dus een breken met de oude, zoo algemeen beproefde en nog geldende wet, waarbij alle Vertebraten, naar het schijnt, tot nu toe zoo welvaren. Het resultaat van dit breken met deze algemeen geldende wet bestaat in de ontwikkeling van een nieuwe, ongekende schoonheid (voor het menschlijk oog en, naar ik meen, evenzeer voor het oog der vogels) van het veerkleed. Merkwaardig is het en zeer zeker opmerkenswaard, dat de enkele hier genoemde en misschien ook een enkele hier niet-genoemde soort door deze waarschịjnlijk zoo opvallende kleur niet uitgeroeid werd. Merkwaardig is het tevens en van belang er aan toe te voegen, dat alle vijf de hier genoemde soorten juist die soorten van fazanten zijn, welke eerst na 13 of 14 maanden hun volle kleur verkrijgen en waarbij zich dus, wat veerenkleed betreft, nog onvolwassen hanen kunnen voortplanten. Dat jonge dieren van 10 tot 12 maanden zich bij fazanten reeds kunnen voortplanten, is intusschen regel. Ik meen, dat iets dergelijks bij de Paradijsvogels eveneens vermoed wordt. Bij Paradijsvogels is het echter nooit bewezen. $\mathrm{Bij}$ het kweeken van fazanten is het mij nu gebleken, dat men, ondanks allen tegenspraak der kweekers, zeer goede resultaten verkrijgen kan uit de paring van nog niet op kleur gekomen hanen, zelfs met jonge, eenjarige hennen.

Aan het voor fazanten ongewone verschijnsel (het eerst op kleur komen na 13 of 14 maanden) hebben waarschijnlijk deze vogels het te danken, dat de schitterende kleuren der hanen de soort niet in het verderf stortten. Immers nu kan er steeds een voldoend aantal nog niet op kleur gekomen jonge hanen aan de voortplanting deelnemen.

Conclusies :

$1^{\circ}$. Het blijkt, dat bij de hanen dezer vogelsoorten slechts bij jonge dieren het kleurpatroon aan de algemeen geldende Vertebraten-wet voldoet n.l.: De rugzijde der Vertebraten is donkerder van kleur dan de buikzijde bij hetzelfde dier. Hierop maken deze volwassen hanen derhalve een uitzondering.

$2^{\circ}$. Het is waarschijnlijk, dat er een meer dan toevallig verband bestaat tusschen het op kleur komen der jonge hanen dezer soorten op den leeftijd van 13 of 14 maanden eenerzijds en het afwijken van de volwassen hanen van de voor alle Vertebraten geldende, onder $1^{0}$. genoemde wet andererzijds.

\section{$\mathrm{N}^{0}$. 44. Phasianidae.}

Bij alle, door mij onderzochte Phasianidae is het mij opgevallen, dat het donsachtig veergedeelte aan den veervoet in relatieve grootte verschilt ten opzichte van de rest van de veervlag. Het moet wel iedereen opvallen, dat aan de rugzijde van den vogel het donsgedeelte der contourveeren op den kop minimaal klein is, terwijl men, te rekenen vanaf het begin van het. zadel, een relatief veel grooter donsdragend, basaal veergedeelte aantreft. Bij de staartpennen en bij de staartdekveeren is het donsachtig, basale gedeelte wederom klein, terwijl ook aan de kopzijde van den vogel de meest-proximale veeren de ontwikkeling van de donsachtige, basale voetstukken in de geringste mate vertoonen. Bij de eigenlijke zadelveeren is derhalve de ontwikkeling van het donsachtige, basale gedeelte relatief het grootste.

Conclusie:

$\mathbf{1}^{0}$. Het blijkt, dat men, naar de donsachtige voetstukken der veeren, de rugzijde van den vogel in vier deelen kan indeelen:

a. (Voorste kopgedeelte). Haast geen donsachtig voetstuk aanwezig.

b. (Van a tot zadelveld). Donsachtig voetstuk grooter dan bij a, maar toch zwak ontwikkeld.

c. (Zadel). Donsachtig voetstuk sterk ontwikkeld.

d. (Staartdek en staartpennen). Haast geen donsachtig voetstuk aanwezig.

\section{$\mathrm{N}^{0}$. 45. Pavo hybridus $\sigma^{7}$ (P. cristatus $\times$ P. cristatus var. alba).}

Meerdere bastaardhanen vertoonen een merkwaardig veerkleed. De vogels zijn ten deele met gekleurde, ten deele met witte veeren bedekt. De witte veeren staan echter niet wille- 
keurig door elkaar, doch in zeer bepaalde regelmaat, op den vogel, zoodat zij veervelden vormen. Deze veervelden zijn bij alle vijf de exemplaren, welke mij bekend zijn, volkomen dezelfde naar vorm en uitbreiding. Merkwaardig is het tevens, dat deze witte velden, welke hier optreden, bij de ouders niet door zichtbare velden vertegenwoordigd worden. Wel is de veldverdeeling een dusdanige, en dit is des te merkwaardiger, dat men haar vergelijken kan met veervelden, welke bij geheel andere vogels optreden. Zoo zijn de grenzen van het witte veld, dat aan den hals optreedt, zeer typisch. Men vindt daar een gekleurde, spitse, tandvormige uitlooper van gekleurde veeren in het witte veerveld binnendringen. De vorm en ligging van dezen tand van gekleurde veeren is geheel dezelfde als bij den tand, welke bij Casuarius aan den hals optreedt, maar hier bestaat uit donkere veeren, welke in een naakt halsgedeelte a. h. w. binnendringen.

Conclusies:

$1^{0}$. Het blijkt, dat bij bastaarden een nieuw veerveld kan optreden, hetwelk bij geen der beide ouders zichtbaar was.

$2^{0}$. Het blijkt, dat het onder $1^{0}$. bedoelde veerveld op verwantschap wijst van twee ver-verwijderde genera (Pavo en Casuarius).

\section{$N^{0}$. 46. Thaumalea $\delta^{x}$ en Phasianus $\sigma^{x}$.}

Vergelijkt men de witte kraagveeren van den Amherstfazant-haan met de veeren van den witten halsband, welke bij vele soorten van Phasianus optreedt, dan ziet men, dat bij beide genera de halsbandveeren principieel slechts in lengte verschillen. De onderlinge vruchtbaarheid dezer beide genera, als ook andere vergelijkingspunten in het veerkleed, welke men voor het veerpatroon kan opstellen, bevestigen dit inzicht.

Ook bij de Phasianus-soorten, welke geen witten halsband dragen (b. v. Ph. colchicus), vindt men bij raszuivere vogels somtijds toch een enkel wit vlekje op de halsveeren ter plaatse, waar de dwarsband normaliter bij de andere soorten optreedt. Ik trof bij Ph. colchicus een dergelijk veertje aan op de linker zijde van den hals. Dit veertje droeg een wit vlekje op een der beide vlaghelften. Volkomen symmetrisch gelegen ten opzichte van dit veertje vond ik op de rechter zijde van den hals een veertje, dat een wit vlekje op de andere vlaghelft droeg. De typische ligging dezer vlekjes op de beide veertjes bewijst reeds voldoende, dat wij hier niet met toevallige vlekjes te doen hebben.

Conclusies:

$1^{0}$. Het blijkt, dat Phasianus en Thaumalea een zeer verwant patroon vertoonen.

$2^{0}$. Het blijkt, dat schijnbaar-toevallige vlekjes op een veer een aanduiding kunnen zijn van een bij andere, naverwante soorten optredend, hier niet-7ichtbaar veerpatroon.

\section{Opsomming der meer algemeene Conclusies.}

Het leek mij wenschelijk toe hier een opsomming van alle, meer algemeene conclusies te laten volgen, welke uit de "Nadere beschrijving van eenige veerpatronen bij Hoenderachtige Vogels" getrokken zijn. Immers het "Overzicht" berust voor het grootste deel op deze conclusies. Daarom ook meende ik gerechtigd te zijn de ordening dezer conclusies bij deze opsomming min of meer aan het toeval over te laten, daar men immers een geordend inzicht als het ware door het "Overzicht" verkrijgt. Achter elk der hier genoemde conclusies heb ik de nummers opgegeven, welke verwijzen naar de nummers der beschrijvingen $\left(\mathrm{N}^{0} \mathrm{~s}\right.$.) van de veerpatronen (pag. 12 tot en met 42). Een enkele maal voegde ik er een conclusie aan toe, welke ook uit het onderzoek van vroegere schrijvers volgde of er mede in strijd is, en welke daaruit reeds als bekend verondersteld kon worden. De bij enkele dezer nummers geplaatste auteursnamen verwijzen naar het „Literatuur-overzicht". De op den auteur betrekking hebbende nummers zijn dezelfde als de nummers, welke men in het literatuur-overzicht vinden kan. Het spreekt wel van zelf, dat niet al deze conclusies geheel nieuw zijn. 
De verwijzing naar de nummers dezer opsomming van conclusies geschiedt onder $\mathrm{n}^{0}$. (kleine $\mathrm{n}$ ).

Ik laat hier derhalve mijn conclusies een voor een volgen. Aldus:

$\mathrm{n}^{0}$. 1. Er bestaat samenhang tusschen vlekken en dwarsbanden. No s. 1, 10, 15, 19, 22, DARwin $1^{\circ}$.

no. 2. Veeren vertoonen, wat betreft de ontwikkeling van haar patroon, richtingsvoorkeur: de overdwarse, de overlangsche, de randstandige. Dit in tegenstelling met de meeningen van vroegere onderzoekers, welke steeds van bepaalde figuren (dwarsband, stip, overlangsche band enz.) spreken. De veerpatroon-ontwikkeling gaat niet volgens bepaalde figuren, maar volgens bepaalde richtingen van ontwikkeling. $\mathrm{N}^{0} \mathrm{~s} .1,15,19,22,25$.

$n^{0}$. 3. Er bestaat samenhang tusschen stippen en randstandige strepen $\mathrm{N}^{0} .2$.

$\mathrm{n}^{0}$. 4. Asymmetrie van het veerpatroon kan optreden, zonder dat hiermede asymmetrie van den veervorm gepaard gaat. $\mathrm{N}^{0} \mathrm{~s} .2,3$.

$\mathrm{n}^{0}$. 5. Het veerpatroon berust niet uitsluitend bij de veer, maar bij een grooter eenheid. $\mathrm{N}^{0} \mathrm{~s} .2$, $14,28,29$.

$\mathrm{n}^{0}$. 6. De schacht van de veer is ten opzichte van het veerpatroon een merkwaardige lijn. . $\mathrm{N}^{\circ} \mathrm{s} .2,28,29$.

$\mathbf{n}^{0}$. \%. Linker en rechter vlaghelft eener zelfde veer gedragen zich ten opzichte van elkaar min of meer zelfstandig. $\mathrm{N}^{0} \mathrm{~s} .2,3,6,8,9$.

$\mathrm{n}^{0}$. 8. Linker en rechter vlaghelft eener zelfde veer zijn in aanleg gelïk. $\mathrm{N}^{0} .3$.

$\mathrm{n}^{0}$. 9. De veerschacht is in principe een lijn van "spiegelende" symmetrie. $\mathrm{N}^{0} \mathrm{~s} .3,23$.

$\mathrm{n}^{0}$. 10. Er bestaat samenhang tusschen randstandige banden en dwarsbanden. $\mathrm{N}^{0} \mathrm{~s} .2,3,31$.

$n^{0}$. 11. Randstandige banden en dwarsbanden zijn wel uit hetzelfde materiaal, hetzelfde pigment opgebouwd, maar zij zijn daarom nog niet gelijkwaardige grootheden. $\mathrm{N}^{0} \mathrm{~s} .3,31,32$.

$\mathrm{n}^{0}$. 12. Het begrip ondergrond, dat bij definitie gesteld werd, heeft slechts descriptieve waarde. $\mathrm{N}^{0}$ s. 3, $1 \%, 22$.

$n^{0}$. 13. Veeren van een zelfden vogel, op de rij af onderzocht, vertoonen geleidelijke overgangsvormen van patroon tot patroon, van veerveld tot veerveld. $\mathrm{N}^{0} \mathrm{~s} .3,14,17,21,22,28,29,38$.

$\mathrm{n}^{0}$. 14. Met een stooring in den veergroei kan een wijziging van het veerpatroon samengaan. $\mathrm{N}^{0} .4$.

$\mathbf{n}^{0}$. 15. Een veerpapil kan een ander patroon als het voor haar normale doen ontstaan. Nos. 4,5 .

$n^{0}$. 16. Er bestaat samenhang tusschen vele op het oog geheel verschillende patronen van een zelfden vogel. $\mathrm{N}^{0} \mathrm{~s} .4,6,23$.

$n^{0}$. 17. Een veerpapil kan aan den top der veer een ander veerpatroon ontwikkelen als aan de lager gelegen deelen derzelfde veer. $\mathrm{N}^{0} \mathrm{~s} .4,5$.

$\mathrm{n}^{0}$. 18. Rechter en linker vlaghelft eener zelfde veer kunnen in hare uitingen geheel zelfstandig worden. $\mathrm{N}^{0} \mathrm{~s} .5,8,13$.

no. 19. Ongepaarde, op de schacht gelegen ocelli, ringvlekken en vlekken hebben twee centra. Zij zijn dus feitelijk dubbel van aanleg. $\mathrm{N}^{0} \mathrm{~s} .6,8,9,19,25$.

$\mathrm{n}^{0}$. 20. Ocelli hebben hun ontstaan te danken aan een onvorming van het dwarsbandenpatroon. $\mathrm{N}^{\circ} \mathrm{s} .6, \mathrm{\gamma}, 9,12,13,21$.

no. 21. Veeren, welke ocelli aan den veertop dragen, bewijzen, dat de veertop niet steeds primitief van patroon is. $\mathrm{N}^{\prime} \mathrm{s} .6,9,19$.

$\mathrm{n}^{0}$. 22. In verband hiermede: Veeren, welke ocelli midden op de veervlag dragen, bewijzen, dat het veermidden niet steeds primitief van patroon is. $\mathrm{N}^{0} \mathrm{~s} .6,9$. 
$n^{0}$. 23. Eveneens in verband hiermede: Veeren, welke ocelli in een overlangschen rij langs de veerschacht dragen, bewijzen, dat 0 . a. het basale gedeelte der veer niet steeds primitief van patroon is. Argusianus (remiges primarii).

$\mathrm{n}^{0}$. 24. Dezelfde veerpatronen kunnen bij verschillende veeren ten opzichte van hun plaatsing op iedere veer verschillend gelegen zijn. $\mathrm{N}^{0} \mathrm{~s} .6,24$.

$\mathrm{n}^{0}$. 25. Ongepaarde, op de schacht gelegen ringvlekken houden verband met dwarsbanden. $\mathrm{N}^{0} .10$.

$\mathrm{n}^{0}$. 26. Het begrip ocellus heeft zonder nadere toelichting slechts descriptieve waarde. №. 13, Pavo, Argusianus, Polyplectron.

$\mathrm{n}^{0} .2 \%$. Een zelfde veerveld kan bij een zelfde vogelfamilie soms primitief en soms secundair gewijzigd zijn. $\mathrm{N}^{0} \mathrm{~s}^{\cdot} \%, 19,20$.

n ${ }^{0}$. 38. Eumer's wet aangaande de postero-anteriore ontwikkeling bezit stellig geen algemeene geldigheid. $\mathrm{N}^{0} \mathrm{~s} . \%, 19,20$. Zie ook $\mathrm{n}^{0} 43$.

no. 29. Op de meestal-aan-het-oog-onttrokken plaatsen van het vogellichaam kunnen sterk gewijzigde, secundaire patronen dragende veeren optreden. $\mathrm{N}^{0} . \%$.

no. 30. Zeer sterke asymmetrie van de veer uit zich meestal zoowel in veervorm als in veerpatroon. $\mathrm{N}^{0} \mathrm{~s} .8,13$.

$\mathrm{n}^{0}$. 31. Asymmetrie van de veer behoeft zich echter niet tegelijkertijd in vorm, kleur en teekening te uiten. $\mathrm{N}^{\circ} .33$.

$\mathrm{n}^{0}$. 32. De asymmetrie van de veer hangt met de symmetrie van het lichaam samen. $\mathrm{N}^{0} .13$.

no. 33. Bij de hoenderachtige vogels treedt ter weerszijde van de veerschacht een typische strook op, welke zich als 't ware bij voorkeur tot secundaire differentiaties leent. Nos. 9, 12, 25, 26.

$\mathrm{n}^{0}$. 34. Bij de hoenderachtige vogels treedt een breede, op korten afstand van den veertop gelegen dwarsband op, welke zich als het ware bij voorkeur tot secundaire differentiaties leent. $\mathrm{N}^{0} \mathrm{~s} .5,6, \%, 12,13,18,21$.

$n^{0}$. 35. Er bestaat samenhang tusschen dwarsrijen van ringvlekken en complexe dwarsbanden. $\mathrm{N}^{0}$ s. $10, D_{\text {ARWIN }} 1^{0}$.

$\mathrm{n}^{0}$. 36. De eene vlaghelft eener zelfde veer kan een phylogenetisch jonger stadium vertoonen dan de andere vlaghelft dier zelide veer. $\mathrm{N}^{0} .13$.

$n^{0}$. 3\%. Ongelijkheid der vlaghelften eener veer ten opzichte van elkaar berust niet op hermaphroditisme. Dit is in strijd met de meening van Bond. No. 13.

$\mathbf{n}^{0}$. 38. De metaalglans (struktuurkleur) ontwikkelt zich bij de veeren onafhankelijk van de verdere differentatie der veerkleur. $\mathrm{N}^{0} .11$.

$\mathrm{n}^{0}$. 39. De metaalglans (structuurkleur) der veeren is aan dezelfde regels of wetten onderworpen als de andere veerkleurfactoren. $\mathrm{N}^{0}$. 11 .

$\mathrm{n}^{0}$. 40. De scheiding tusschen twee veerpatronen is onafhankelijk van de individualiteit der veer. $\mathrm{N}^{0} .14$.

$\mathrm{n}^{0}$. 41. Een zelfde veerpapil kan tegelijkertijd in twee veervelden wortelen. $\mathrm{N}^{\circ} \mathrm{s} .14,28$.

$\mathrm{n}^{0}$. 42. Het voorkomen van twee patronen op dezelfde veer levert, in het geval dat deze patronen van elkaar gescheiden zijn door een grens evenwijdig aan de veerschacht, geen afdoend bewijs op voor de verwantschap dier beide patronen. $\mathrm{N}^{0}$. 14 .

$\mathbf{n}^{0}$. 43. De overlangsche strepen of banden op een veer ontstaan op verschillende wijzen. Aldus: a. Door samenstelling van twee veerpatronen op een veer. $\mathrm{N}^{0} .14$.

b. Door uitrekking van een vlekteekening. $\mathrm{N}^{0} .20$.

c. Door het in overlangsche richting versmelten van dwarsstrepen of dwarsbanden. $\mathrm{N}^{0} .26$. 
d. Door een plotseling ontstaan als overlangsche band. Deze overlangsche veerstrooken schijnen geen verband te houden met de primitieve dwarsbandteekening. $\mathrm{N}^{0} \mathrm{~s} .9,12,25,26$.

$\mathrm{n}^{0} .44$. Het begrip overlangsche streep of overlangsche band heeft slechts descriptieve waarde. $\mathrm{N}^{\circ}$ s. $9,12,14,20,25,26$.

$\mathrm{n}^{0}$. 45. Ingewikkelde veerpatronen vertoonen samenhang met dwarsbandenteekening. $\mathrm{N}^{\mathrm{s}} \mathrm{s} .15,19$, $20,23,25,26,2 \%$.

$\mathrm{n}^{0}$. 46. Veervorm en veerkleur zijn onafhankelijk van elkaar overerfbaar. $\mathrm{N}^{0} .16$.

$\mathrm{n}^{0}$. 4\%. Veervorm en veerteekening zijn onafhankelijk van elkaar overerfbaar No. 16.

$\mathrm{n}^{0}$. 48. Veerkleur en veerteekening zijn onafhankelijk van elkaar overerfbaar. $\mathrm{N}^{0} \mathrm{~s} .16,25,2 \%$.

$n^{0}$. 49. Veerpatronen kunnen ook dan vergelijkbaar en verwant zijn, wanneer zij uit ongelijke kleuren zijn opgebouwd. $\mathrm{N}^{0}$ s. $16,1 \%, 25,26,2 \%, D_{\text {ARwin }} 3^{0}$.

no. 50. De aan de rugzijde gelegen veervelden van een vogel vertoonen een inniger samenhang met elkaar dan met de aan de buikzijde gelegen veervelden van denzelfden vogel. De vogel is verdeeld (volgens de veervelden) in een rug- en een buiksector. $\mathrm{N}^{0} .17$.

$n^{0}$. 51. Het buikveld van een vogel kan minder primitief zijn dan het rugveld $\mathrm{N}^{0} .20$.

$n^{0}$. 52. Bij de soorten der hoenderachtige vogels, waar de volwassen hanen een lichter rugsector en een donkerder buiksector bezitten, gehoorzamen de jonge vogels toch aan de algemeen geldende Vertebraten-wet: De rugzijde der Vertebraten is bij dezelfde dieren donkerder van kleur dan de buikzijde. $\mathrm{N}^{\circ} .43$.

$n^{0}$. 53. Er bestaat een meer dan toevallig verband bij de onder $n^{0} .52$ bedoelde soorten tusschen het op kleur komen der jonge hanen op den leeftijd van 13 of 14 maanden eenerzijds en het afwijken door de volwassen hanen van de hierboven genoemde Vertebraten-wet andererzijds. No. 43.

n. 54. Een zelfde vlekteekening kan zoowel met dwarsbanden als met overlangsche banden samenhangen. $\mathrm{N}^{0} .20$.

$\mathrm{n}^{0}$.55. Overlangsche streepteekening of bandteekening is niet per se een phylogenetisch oude teekening. Dit is in strijd met Ermen's wet. Zie $n^{0} .43$.

$\mathrm{n}^{0}$. 56. Een van hetzelfde vogelindividu genomen veerreeks is geen phylogenetische reeks. Dit is in strijd met Kurschner's meening. N $\mathrm{N}^{0}$ s. 21, Darwin $2^{0}$, Kerschner $6^{0}$.

$\mathrm{n}^{0} .5 \%$. Het begrip veerteekening heeft slechts descriptieve waarde. $\mathrm{N}^{0} .22$.

$\mathrm{n}^{0}$. 58. Daar het dwarsbandenpatroon in verband gebracht kan worden met ingewikkelde patronen, welke bij de volwassen hanen en soms bij de volwassen hennen optreden, is het dwarsbanden patroon een primitief patroon. Hierop wijst eveneens het voorkomen van het dwarsbandenpatroon of dwarsstrepenpatroon bij alle jonge hanen en jonge hennen en bij de meeste volwassen hennen. Dit is in overeenkomst met Ermer's meening. Eimer $1^{0}$.

$\mathrm{n}^{0}$. 59. Het vergelijkbaar patroon van een veer kan bij een andere veer slechts een deel van het veeroppervlak beslaan. $\mathrm{N}^{0} \mathrm{~s} .24,26,2 \%$.

$\mathrm{n}^{0}$. 60. Het manlijke veerpatroon en het vrouwlijke veerpatroon van een zelfde species vertoont een zeer duidelijke samenhang, ook waar dit op het eerste gezicht niet zoo lijkt. $\mathrm{N}^{0}$ s. $26,2 \%$.

$n^{0}$. 61. Er bestaat samenhang tusschen scheefgestelde dwarsbanden en echte dwarsbanden. Evenwel zijn beide soorten banden niet identiek gelijk. $\mathrm{N}^{0} .26$.

$n^{0}$. 62. Het arrhenoide, vrouwlijk patroon vormt bij fazanten een overgangsstadium tusschen het echte manlijke en het echte vrouwlijke patroon derzelfde vogelsoort. $\mathrm{N}^{0} .26$. 
$\mathrm{n}^{0}$. 63. Het veerpatroon van den jongen haan vormt bij fazanten een overgangsstadium tusschen het echte manlijke en het arrhenoide vrouwlijke patroon derzelfde vogelsoort $\mathrm{N}^{0} .26$.

$n^{0}$. 64. Arrhenoide veerpatronen wijzigen zich bij een zelfde vogelsoort, met den leeftijd der bennen mede, steeds meer in manlijken zin. $\mathrm{N}^{0} .42$.

n. 65. De omvorming van een dwarsbanden dragende, manlijke of vrouwlijke veer tot een het manlijk karakter dragende veer, hoe verschillend dit manlijke veerpatroon of de verschillende veervelden van het lichaam ook zijn mogen, geschiedt bij een vogel in denzelfden zin. $\mathrm{N}^{\circ} \mathrm{s} .26,42$.

no. 66. Phasianus en Syrmaticus dragen veeren, welke van een zelfde gemeenschappelijk patroon afgeleid kunnen worden. De indeeling der fazanten in verschillende genera, zooals deze op het oogenblik is, is een onjuiste. $\mathrm{N}^{0} .26$. (Vergelijk $\mathrm{N}^{0} .46$ en $\mathrm{n}^{0} .91$ ).

$\mathrm{n}^{0} .67$. Een niet-primitief gekleurde hen vertoont een veerpatroon, dat het best vergelijkbaar is met het veerpatroon eener arrhenoide hen. $\mathrm{N}^{0} \mathrm{~s} .26,2 \%$.

$n^{0}$. 68. Somtijds kan men ingewikkelde veerpatronen van een haan en een hen derzelfde soort eerst met elkaar in verband brengen door vergelijk met andere genera. $\mathrm{N}^{0} .2 \%$.

$\mathrm{n}^{0}$. 69. Bij een zelfde veer kan vormverandering en kleurverandering samengaan. Dit hoeft echter volstrekt niet het geval te zijn. No. 28 .

$\mathrm{n}^{0}$. \%0. Door bastaardeering kan bij den bastaard een kleurveld optreden, dat bij geen der beide ouders zichtbaar was. $\mathrm{N}^{0}{ }^{\mathrm{s}}$. 28,45 .

n. \%1. De oorspronkelijke dwarsbandteekening eener veer kan, ondanks de overdekking door een later optredend, zwart pigment en ondanks het optreden van den metaalglans (structuurkleur), toch nog in de veer aanwezig zijn. No. 29.

n. 72. Een veerkleed bestaat meestal uit meer dan een veereditie. No. 32, (WEBEr "Biologie").

no. \%3. Een veer van de jeugd-editie kan, wat den vorm betreft, nader verwant zijn aan veeren van een ander genus dan de veeren van latere veeredities van denzelfden vogel. $\mathrm{N}^{0}$. 32 .

$\mathrm{n}^{0}$. 74. De vorm der veeren wijzigt zich, ook nog bij den volwassen vogel, met iedere veereditie. $\mathrm{N}$ is. 32, 33.

$\mathrm{n}^{0}$. 75. De kleur der veeren wijzigt zich, ook nog bij den volwassen vogel, met iedere veereditie. $\mathrm{N}^{0} \mathrm{~s} .32,33$.

$\mathrm{n}^{0}$. \%6. De teekening der veeren wijzigt zich, ook nog bij den volwassen vogel, met iedere veereditie. $\mathrm{N}^{0} \mathrm{~s} .32,33$.

$n^{0}$. $\%$ \%. De rugas van een vogel kan, wat veervorm betreft, een lijn van symmetrie zijn. $\mathrm{N}^{0} .35$.

nº \%8. De rugas van een vogel kan, wat veerkleur betreft, een lijn van symmetrie zijn. $\mathrm{N}^{0} .36$.

$\mathrm{n}^{0}$. \%9. De rugas van een vogel kan, wat veerteekening betreft, een lijn van symmetrie zijn No. 34.

$n^{0}$. 80. De grenslijn tusschen twee veervelden van een zelfden vogel behoeft voor de veerkleur en den veervorm niet volkomen dezelfde te zijn. $\mathrm{N}^{0}$. 36 .

$n^{0}$. 81. De borst-middellijn van een vogel kan, wat de veerteekening betreft, een lijn van symmetrie zijn. No. $3 \%$.

$\mathrm{n}^{0}$. 82: De borst-middellijn van een vogel kan, wat de veerteekening betreft, een lijn van symmetrie zijn. $\mathrm{N}^{0}$. $3 \%$.

$\mathrm{n}^{0}$. 83. De veervlag heeft een dorsaal- en een ventraal-patroon. $\mathrm{N}^{0} \mathrm{~s} .25,39$. 
$\mathrm{n}^{0}$. 84. Bij hoenderachtige vogels dragen de achterschacht en de daarbij behoorende achtervlag der veer slechts bij hooge uitzondering een dwarsbandteekening. No. 39.

$\mathrm{n}^{0}$. 85. De lichte, overlangsche kuikenstrepen stellen de grenzen voor van het later eerst naar veervorm, veerkleur en veerteekening gedifferentieerde zadelveld. No. 40 .

$\mathrm{n}^{0}$. 86. De overlangsche kuikenstrepen houden geen verband met de overlangsche strepen of banden der veeren. No. 40.

$n^{0} .8 \%$. Tweemaal de veerschacht snijdende, randstandige banden zijn, evenals eenmaal de veerschacht snijdende, randstandige banden, met echte dwarsbanden verwant. $\mathrm{N}^{0}$. 31 .

$n^{0}$. 88. De verschillende soorten van banden en strepen ontstaan uit elkaar door een vervorming (versmelting en oplossing) en niet door een omvorming. $\mathrm{N}^{0} .31$.

$\mathrm{n}^{0}$. 89. Men kan, naar de donsachtige voetstukken der veeren, de rugzijde van den vogel in vier deelen indeelen:

a. (Voorste kopgedeelte). Haast geen donsachtig voetstuk aanwezig.

$b$. (Van $a$ tot zadelveld). Donsachtig voetstuk grooter dan bij $a$, maar toch zwak ontwikkeld.

c. (Zadel). Donsachtig voetstuk sterk ontwikkeld.

d. (Staartdek en staartpennen). Haast geen donsachtig voetstuk aanwezig.

$\mathrm{N}^{0} .44$.

$n^{0}$.90. Uit het optreden van een nieuw kleurveld bij een bastaard tusschen twee varieteiten of twee soorten kan verwantschap blijken te bestaan tusschen deze beide varieteiten of soorten met een derde ver-verwijderde soort. $\mathrm{N}^{0} \mathrm{~s} .28,45$.

$\mathrm{n}^{0}$.91. Phasianus en Thaumalea dragen veeren, welke van een gemeenschappelijk patroon afgeleid kunnen worden. De indeeling der fazanten in verschillende genera, zooals deze op het oogenblik is, is een onjuiste. $\mathrm{N}^{0} .46$. (Vergelijk $\mathrm{N}^{0} .26$ en $\mathrm{n}^{0} .66$ ).

$n^{0}$.92. Schijnbaar-toevallige vlekjes op een veer kunnen een aanduiding zijn van een bij andere, naverwante soorten optredend, hier niet-zichtbaar veerpatroon. $\mathrm{N}^{0} .46$.

$\mathrm{n}^{0}$.93. Veerkleur en veerteekening ontwikkelen zich bij eenzelfden vogel wel in dezelfde richting, maar toch onafhankelijk van elkaar. $\mathrm{N}^{0}$. 42. (Vergelijk $\mathrm{n}^{0}$. 48).

$\mathrm{n}^{0}$. 94. Veervorm en veerteekening ontwikkelen zich bij eenzelfden vogel wel in dezelfde richting, maar toch onafhankelijk van elkaar. $\mathrm{N}^{0}$. 33. (Vergelijk $\mathrm{n}^{0} .4 \%$ ).

$n^{0}$. 95. Veervorm en veerkleur ontwikkelen zich bij eenzelfden vogel wel in dezelfde richting, maar toch onafhankelijk van elkaar. Dit geldt zoo algemeen bij het op kleur komen van hanen en arrhenoide hennen, dat het overbodig was een nadere beschrijving te geven. (Vergelijk $\mathrm{n}^{0}$. 46).

$\mathbf{n}^{0}$. 96. Er zijn drie veeruitingen, waardoor de veer haar typisch uiterlijk verkrijgt, te weten: veervorm, veerteekening, veerkleur. Dit typisch veer-uiterlijk komt tot stand door de combinatie van de graden van ontwikkeling dezer drie factoren, welke onafhankelijk van elkaar, doch aan gelïke wetten gehoorzamend, zich, met de specialiseering der vogelsoorten mede, geleidelijkaan, stap voor stap verder ontplooien. Vergelijk de $n^{0}$ s. 46 , $47,48,74,75,76,7 \%, 78,79,80,81,82,85,93,94,95$. 